\title{
Measurement of scattering and absorption properties of dust aerosol in a Gobi farmland region of northwestern China - a potential anthropogenic influence
}

\author{
Jianrong Bi, Jianping Huang, Jinsen Shi, Zhiyuan Hu, Tian Zhou, Guolong Zhang, Zhongwei Huang, Xin Wang, and \\ Hongchun Jin
}

Key Laboratory for Semi-Arid Climate Change of the Ministry of Education, College of Atmospheric Sciences, Lanzhou University, Lanzhou 730000, China

Correspondence to: Jianping Huang (hjp@lzu.edu.cn)

Received: 22 February 2017 - Discussion started: 1 March 2017

Revised: 19 May 2017 - Accepted: 26 May 2017 - Published: 28 June 2017

\begin{abstract}
We conducted a comprehensive field campaign to explore the optical characteristics of mineral dust in Dunhuang farmland near the Gobi Desert of northwest China during spring of 2012. The day-to-day and diurnal variations of dust aerosol showed prominent features throughout the experiment, primarily attributable to frequent dust events and local anthropogenic emissions. The overall average mass concentrations of the particulate matter with an aerodynamic diameter less than $10 \mu \mathrm{m}\left(\mathrm{PM}_{10}\right)$, light scattering coefficient $\left(\sigma_{\mathrm{sp}, 670}\right)$, absorption coefficient $\left(\sigma_{\mathrm{ap}, 670}\right)$, and single-scattering albedo $\left(\mathrm{SSA}_{670}\right)$ were $113 \pm 169 \mu \mathrm{g} \mathrm{m}^{-3}$, $53.3 \pm 74.8 \mathrm{Mm}^{-1}, 3.2 \pm 2.4 \mathrm{Mm}^{-1}$, and $0.913 \pm 0.05$, respectively, which were comparable to the background levels in the southern United States but smaller than those in the eastern and other northwestern Chinese cities. The anthropogenic dust produced by agricultural cultivations (e.g., land planning, plowing, and disking) exerted a significant superimposed effect on high dust concentrations in Dunhuang farmland prior to the growing season (i.e., from 1 April to 10 May). Strong south valley wind and vertical mixing in daytime scavenged the pollution, and the weak northeast mountain wind and stable inversion layer at night favorably accumulated the air pollutants near the surface. In the afternoon (13:00-18:00 LT, local time), mean $\mathrm{SSA}_{670}$ was $0.945 \pm 0.04$ predominantly from dust particles, whereas finer particles and lower SSA $_{670}$ values $(\sim 0.90-0.92)$ were measured at night, suggesting the potential influence by the mixed dust pollutants. During a typical biomass burning event on 4 April 2012, $\sigma_{\text {ap }, 670}$ increased from $\sim 2.0$ to $4.75 \mathrm{Mm}^{-1}$ and $\mathrm{SSA}_{670}$ changed from $\sim 0.90$ to $\sim 0.83$, implying remark-
\end{abstract}

able modification of aerosol absorptive properties induced by human activities. The findings of this study would help to advance an in-depth understanding of the interaction among dust aerosol, atmospheric chemistry, and climate change in a desert source region.

\section{Introduction}

Asian mineral dust (also known as dust aerosol) in the atmosphere is deemed to exert a profound impact on air quality and climate change. It can perturb the energy budget of the Earth system directly through scattering and absorption of solar and terrestrial radiation (Huang et al., 2009, 2014; Ge et al., 2010; Li et al., 2016) and indirectly by altering cloud microphysical processes and related hydrological cycle (Rosenfeld et al., 2001; J. Huang et al., 2005, 2006, 2010; Yin and Chen, 2007; W. Wang et al., 2010; Creamean et al., 2013; Wu et al., 2016), as well as modifying snow and ice surface albedo (Aoki et al., 2006; Huang et al., 2011; Wang et al., 2013; Qian et al., 2014). In addition, alkaline mineral dust carries abundant organic matters and iron ions deposited on the surface of Earth and hence affects biomass productivity in the North Pacific Ocean and relevant atmosphere-ocean carbon exchange, which plays a pivotal role in the global biogeochemical cycle and carbon cycle (Cao et al., 2005; Jickells et al., 2005; Maher et al., 2010; Shao et al., 2011).

The Taklamakan Desert in northwestern China and Gobi Desert in southern Mongolia and northern China are widely 
regarded as two major active centers of dust storms in East Asia (Sun et al., 2001; Zhao et al., 2006; Wang et al., 2008; Ge et al., 2016). These extensive arid and desert zones frequently generate a great deal of tiny soil particles every spring that are uplifted and entrained into the free atmosphere layer via cold frontal cyclones (Zhang et al., 1997; Aoki et al., 2005; Kai et al., 2008; J. Huang et al., 2009, 2010, 2014). Affected by midlatitude prevailing westerlies, these dust particles can be transported long distances on a subcontinental scale, even sweep across the remote Pacific Ocean and occasionally arrive at the west coast of North America during the peak seasons of strong dust storms (Zhao et al., 2006; Uno et al., 2009, 2011). They then have a far-reaching influence on climatic and environmental changes both regionally and globally. Until now, there have been a large number of intensive field experiments (e.g., ACE-Asia, ADEC, PACDEX, EAST-AIRC) and ground-based aerosol monitoring networks (e.g., AERONET, SKYNET, CARSNET) for probing the Asian mineral dust (Holben et al., 1998; Huebert et al., 2003; Nakajima et al., 2003; Takamura et al., 2004; Eck et al., 2005; Mikami et al., 2006; Huang et al., 2008a; Che et al., 2009, 2015; Li et al., 2011), which are crucial for thoroughly understanding the climatic effects of dust aerosols over East Asian domain. Nevertheless, due to poor sampling of dust aerosols over desert source areas of northwest China, the light scattering and absorption properties of mineral dusts in this region are far inadequate and urgently need to be further surveyed.

The Intergovernmental Panel on Climate Change (IPCC, 2013) reported that the symbol and magnitude of the radiative forcing of mineral dust is greatly reliant on the accurate and reliable knowledge of aerosol total loading, microphysical and chemical characteristics, as well as its spatiotemporal distribution. The current consensus is that nearly pure dust aerosol in the globe has relatively low light absorption, with single-scattering albedo (SSA) of $\sim 0.96-0.99$ (Dubovik et al., 2002; Anderson et al., 2003; Uchiyama et al., 2005; Bi et al., 2014, 2016), which depends principally on the fraction and mixing ways of ferric iron oxides (i.e., hematite and goethite) in dust (Sokolik and Toon, 1999; Lafon et al., 2004, 2006). However, the coexistence of both mineral dust and other types of aerosols originated from diverse human activities (e.g., coal combustion, mobile source emissions, and biomass burning) is ubiquitous in the real atmosphere, which increases the complexity and variability of aerosol key parameters (Arimoto et al., 2004; Xu et al., 2004; Wang et al., 2015). When the lofted dust plumes in desert source areas travel eastward across the polluted regions, they commonly mix with anthropogenic pollutants and enhance heterogeneous chemical reactions with other reactive gas species and then may markedly alter their chemical and microphysical properties (Arimoto et al., 2006; Li and Shao, 2009; Nie et al., 2014). It is well documented that the mineral dust might already mix with polluted aerosols near dust source regions of northwest China (i.e., Inner Mongolian Gobi Desert) before the mixing processes on the transport pathway ( $\mathrm{K}$. Huang et al., 2010). Xu et al. (2004) indicated that both dust aerosol and local pollution sources coexisted in Yulin near the Mu Us Desert of northwest China during April 2001, which produced a significant influence on aerosol properties in the region. Likewise, $\mathrm{Li}$ et al. (2010) analyzed trace gases and aerosols observed at Zhangye $\left(39.082^{\circ} \mathrm{N}, 100.276^{\circ} \mathrm{E}\right.$; $1460 \mathrm{~m}$ above m.s.l.), a rural site within the Hexi Corridor in northwest China during spring 2008, and uncovered that the mixing between mineral dust and anthropogenic air pollutants is omnipresent in this area, including at nighttime or during severe dust events. This implies that prior to moving out from the source region, dust particles were likely related to pollutants. For the sparsely populated and less anthropogenically affected desert source regions in northwest China (e.g., the Taklamakan Desert and its adjacent areas), the interaction between local pollution and mineral dust should be explored in depth. This is of prime importance to ascertain the relative contributions of two different aerosol sources in atmospheric chemistry and regional climate change.

To advance a better understanding of the drought processes and dust-relevant climatic impacts in northwest China (Huang et al., 2008b; Bi et al., 2011; G. Wang et al., 2010), the Semi-Arid Climate and Environment Observatory of Lanzhou University (henceforth referred to as SACOL, http://climate.lzu.edu.cn/english/) carried out a comprehensive field campaign in Dunhuang during spring of 2012. Dunhuang is situated at the westernmost fringe of Hexi Corridor in Gansu province, close to the eastern edge of Kumtag Desert and about $450 \mathrm{~km}$ in the downwind zone of Taklamakan Desert. Dunhuang was an important town on the ancient Silk Road and the transportation junction to the ancient western region, central Asia and Europe; it has become a world-famous tourist city with a residential population of 200 000. Agriculture and tourism are the dominant economic industries in Dunhuang. An array of ground-based remote sensing and in situ instruments were set up during the intensive period, which sought to investigate the key properties of aerosol and its climatic effect on a regional scale (Bi et al., 2014). This study specifically aims to explore the light scattering and absorption characteristics of mineral dust and elucidates a potential anthropogenic influence. In the following, we introduce the site information and integrated measurements in Sect. 2. The primary results and discussion are described in Sect. 3. The concluding remarks are given in Sect. 4, followed by the data availability in Sect. 5 .

\section{Site and instrumentation}

\subsection{Site information}

SACOL's Mobile Facility (SMF) was deployed at Dunhuang farmland $\left(40.492^{\circ} \mathrm{N}, 94.955^{\circ} \mathrm{E} ; 1061 \mathrm{~m}\right.$ above m.s.l.) from 
1 April to 12 June 2012. The site is a tiny, isolated oasis encompassed by the east-west-oriented Gobi Desert and arid zones in northwest China, with the Mingsha Shan (Echoing Sand Mountain; elevation of $\sim 1650 \mathrm{~m}$ ) and Sanwei Mountain (elevation $\sim 1360 \mathrm{~m}$ ) to the southwest and the Beishan Mountain (elevation $\sim 2580 \mathrm{~m}$ ) to the north (Ma et al., 2013). The underlying surface is typically covered with Gobi Desert and saline-alkali land, and the principal vegetation types consist of extremely sparse Alhagi. Dunhuang farmland is an important agricultural base in Gobi Desert, mainly growing hami melon and cotton. There are not any significant manmade pollution sources (e.g., large-scale industries or coal-fired power plants) around the monitoring station. The southwest-northeast-oriented National Highway 215 is about $400 \mathrm{~m}$ west of the site (Fig. 1a). The nearest Xihu township (with total population of 13800) is approximately $7 \mathrm{~km}$ to the north of Dunhuang farmland, along with some scattered villages stretching from west to east. Meanwhile, the station is located in northeastern Dunhuang $(\sim 45 \mathrm{~km})$, to the west of Guazhou county $(\sim 70 \mathrm{~km})$ and to the southwest of Liuyuan town $(\sim 80 \mathrm{~km})$. In general, the major anthropogenic emission sources at Dunhuang farmland likely include coal combustion from domestic heating and cooking, mobile sources emissions from vehicle exhaust gas, and biomass burning from crop residue and traditional ritual activities, which are ordinarily considered to be a puny contribution to the mineral dust in present-day climate models. The climate pattern here is characterized as extreme drought but with a moderate temperature during the whole sampling period (temperature: $18.3 \pm 8.1^{\circ}$; relative humidity (RH): $21.9 \pm 16.5 \%$; mean \pm standard deviation). Thereby the dust storms frequently take place in this region from spring to early summer. Figure $1 \mathrm{~b}$ shows the overall mean UV aerosol index (AI) from 1 April to 12 June 2012 obtained from the Ozone Monitoring Instrument (OMI) absorbing aerosol products (Torres et al., 2007). The AI dataset is a very good indicator for mapping the distribution of absorbing aerosols (mainly black carbon and dust). The distributions of high AI values (>0.7) are consistent with the dust-dominated geomorphological features in arid and semi-arid regions (i.e., Taklamakan Desert and Gobi Desert). It is very obvious that Dunhuang (marked with a star) is also situated at the primary dust belt of northwest China, as presented in Fig. $1 \mathrm{~b}$.

\subsection{Aerosol measurements}

An aerosol integrated observing system is installed in the laboratory of SMF and utilized to continuously measure aerosol optical properties and size distribution in the field. Prior to the experiment, the in situ aerosol instruments and broadband radiometers were newly purchased and calibrated by the manufacturers (Bi et al., 2014). Table 1 summarizes the basic specification, measured variables, and accuracy of surface-based instruments deployed at Dunhuang farmland

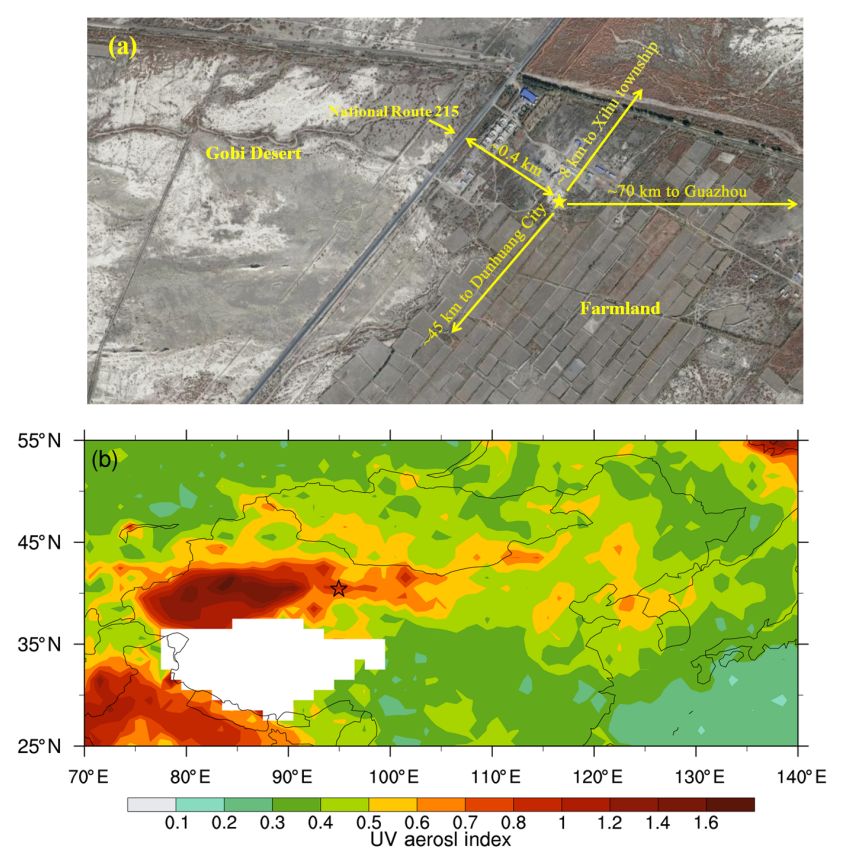

Figure 1. (a) The Dunhuang farmland site $\left(40.492^{\circ} \mathrm{N}, 94.955^{\circ} \mathrm{E}\right.$; altitude: $1061 \mathrm{~m}$ ) labeled with a star and its surrounding region. (b) OMI (Ozone Monitoring Instrument, 2004) mean UV aerosol index from 1 April to 12 June 2012. The site is located in the downwind region of the Taklamakan Desert and frequently experiences dust storms.

throughout the experiment. These instruments are described below.

An ambient particulate monitor (model RP1400a, Rupprecht and Patashnick Corp.) can collect the in situ mass concentration of the particulate matter with an aerodynamic diameter less than $10 \mu \mathrm{m}\left(\mathrm{PM}_{10}\right)$ based on the tapered element oscillating microbalance (TEOM) technique. The measurement range and accuracy of $\mathrm{PM}_{10}$ concentration levels are normally $0-5$ and $0.1 \mu \mathrm{g} \mathrm{m}^{-3}$, respectively. The heating temperature $\left(\sim 50^{\circ}\right)$ of the sampling tube may cause a partial loss of volatile and semivolatile aerosol compounds and hence bring about a negative signal. In this study, we eliminate all the negative values of $\mathrm{PM}_{10}$ concentrations, which account for less than $1 \%$ of total data points.

An integrating nephelometer (model 3563, TSI Inc.) is designed to simultaneously measure the total scattering coefficients $\left(\sigma_{\mathrm{sp}}\right)$ and hemispheric backscattering coefficients $\left(\sigma_{\mathrm{bsp}}\right)$ of aerosol particles at three wavelengths of 450, 550, and $700 \mathrm{~nm}$, with the $\sigma_{\mathrm{sp}}$ detection limits of $0.44,0.17$, and $0.26 \mathrm{Mm}^{-1}\left(1 \mathrm{Mm}^{-1}=10^{-6} \mathrm{~m}^{-1}\right)$, respectively (signal-tonoise ratio of 2) (Anderson et al., 1996). To quantify the instrument drift and improve accuracy, we periodically perform the routine calibration using air and high-purity $\mathrm{CO}_{2}$ gases. Furthermore, the truncation errors of near-forward scattering (i.e., non-ideal angular effects) are corrected according to the method of Anderson and Ogren (1998). The 
Table 1. The main aerosol observation and other ground-based instruments deployed at Dunhuang farmland during spring of 2012.

\begin{tabular}{|c|c|c|}
\hline Measured variables & Model, manufacturer & Accuracy \\
\hline $\mathrm{PM}_{10}$ concentration & $\begin{array}{l}\text { Ambient particulate monitor (RP1400a), R\&P } \\
\text { Corp. }\end{array}$ & $0.1 \mu \mathrm{g} \mathrm{m}^{-3}$ \\
\hline Aerosol scattering coefficient & $\begin{array}{l}\text { Integrating nephelometer (TSI 3563), TSI Inc. } \\
450,550 \text {, and } 700 \mathrm{~nm}\end{array}$ & $\begin{array}{l}0.44,0.17, \text { and } \\
0.26 \mathrm{Mm}^{-1}\end{array}$ \\
\hline Aerosol absorption coefficient & $\begin{array}{l}\text { Multi-angle absorption photometer (MAAP } \\
\text { 5012), Thermo Electron Corp. }\end{array}$ & $0.66 \mathrm{Mm}^{-1}$ \\
\hline Aerosol size distribution & $\begin{array}{l}\text { Aerodynamic particle sizer (APS 3321), TSI } \\
\text { Inc., } 0.5-20 \mu \mathrm{m}\end{array}$ & $0.001 \mathrm{~cm}^{-3}$ \\
\hline Aerosol-attenuated backscatter profile & Micro-pulse lidar (MPL-4), Sigma Space Corp. & $\begin{array}{l}\text { Spatial resolution: } \\
\sim 30 \mathrm{~m}\end{array}$ \\
\hline Meteorological elements & $\begin{array}{l}\text { Weather transmitter (WXT520), Vaisala, Ta, } \\
\text { RH, P, u, WD }\end{array}$ & $\begin{array}{l}\text { Ta: } \pm 0.3^{\circ} \text {; RH: } 0.1 \% \text {; } \\
\text { P: } 0.1 \mathrm{hPa} \text {; u: } 0.1 \mathrm{~ms}^{-1} \text {; } \\
\text { WD: } 1^{\circ}\end{array}$ \\
\hline Global and diffuse radiation & $\begin{array}{l}\text { Pyranometer }\left(\text { PSP }^{\mathrm{a}, \mathrm{b}}\right) \text {, Eppley Lab., } \\
0.285-2.8 \mu \mathrm{m}\end{array}$ & $\begin{array}{l}\text { Global: } 8.46 \text {; diffuse: } \\
8.48 \mu \mathrm{VW}^{-1} \mathrm{~m}^{-2}\end{array}$ \\
\hline Direct radiation & $\begin{array}{l}\text { Pyrheliometer }\left(\mathrm{NIP}^{\mathrm{b}}\right) \text {, Eppley Lab., } \\
0.285-2.8 \mu \mathrm{m}\end{array}$ & $8.38 \mu \mathrm{VW}^{-1} \mathrm{~m}^{-2}$ \\
\hline Downward longwave radiation & Pyrgeometer $\left(\mathrm{PIR}^{\mathrm{a}, \mathrm{b}}\right)$, Eppley Lab., 3.5-50 $\mu \mathrm{m}$ & $2.98 \mu \mathrm{VW}^{-1} \mathrm{~m}^{-2}$ \\
\hline 24-bit color JPEG image & $\begin{array}{l}\text { Total Sky Imager (TSI880), YES Inc., } \\
352 \times 288 \text { pixel }\end{array}$ & Sampling rate: $1 \mathrm{~min}$ \\
\hline
\end{tabular}

a The instrument is equipped with the Eppley ventilation system (VEN).

b The instrument is mounted on a two-axis automatic sun tracker (model 2AP, Kipp \& Zonen).

observed ambient RH values are mostly smaller than $40 \%$ throughout the entire period. It is well documented that RH induced the variations in aerosol light scattering coefficients are minimized under a low sampling stream RH of 10-40\% (Covert et al., 1972). In this paper, we computed the scattering Ångström exponent at 450-700 nm (SAE 450/700 nm) from $\sigma_{\mathrm{sp}}$ at $450 \mathrm{~nm}$ and $\sigma_{\mathrm{sp}}$ at $700 \mathrm{~nm}$ by utilizing a log-linear fitting algorithm. Thus $\sigma_{\mathrm{sp}}$ at $670 \mathrm{~nm}\left(\sigma_{\mathrm{sp}, 670}\right)$ was logarithmic interpolated between $\sigma_{\mathrm{sp}, 450}$ and $\sigma_{\mathrm{sp}, 700}$.

A multi-angle absorption photometer (MAAP model 5012, Thermo Electron Corp.) is capable of observing the aerosol light absorption coefficient at $670 \mathrm{~nm}\left(\sigma_{\mathrm{ap}, 670}\right)$ by filter-based methods without requiring of post-measurement data correction or parallel-measured aerosol light scattering coefficients (Petzold et al., 2002). The instrument detects an emitted light at $670 \mathrm{~nm}$ in the forward and back hemisphere of airborne aerosols deposited on a fiber filter, which is used to improve multiple scattering effects in the aerosol optical properties via a radiative transfer scheme (Petzold et al., 2002, 2005). The sample flow rate is $1000 \mathrm{~L} \mathrm{~h}^{-1}$, with flow error of $<1 \%$. We made use of a specific absorption efficiency at $670 \mathrm{~nm}$ of $6.5 \pm 0.5 \mathrm{~m}^{2} \mathrm{~g}^{-1}$ to estimate black carbon concentration from $\sigma_{\mathrm{ap}, 670}$ as recommended by Petzold et al. (2002).
An Aerodynamic Particle Sizer (APS) spectrometer (model 3321, TSI Inc.) can continuously provide the realtime, high-resolution aerosol size distribution with aerodynamic diameters from 0.5 to $20 \mu \mathrm{m}$ range (52 channels). When extreme dust episodes outbreak, an aerosol diluter (model 3302A, TSI Inc.) is operated in series with APS to reduce particle concentrations in high-concentration aerosols, which offers a representative sampling that meets the input requirements of the APS spectrometer. All the abovementioned aerosol datasets were acquired at $5 \mathrm{~min}$ and hourly averages and reported for sampling volumes under standard air conditions (i.e., $1013.25 \mathrm{hPa}$ and $20^{\circ}$ ).

\subsection{Other ground-based measurements}

A micro-pulse lidar (model MPL-4, Sigma Space Corp., USA) is a compact and unattended apparatus for providing continuous data information of extinction coefficient and depolarization ratio profiles of aerosols and clouds (Welton et al., 2000). The MPL-4 emits a laser beam at a wavelength of $527 \mathrm{~nm}$ from a Nd:YLF pulsed laser diode and receives the attenuated backscattering intensity and depolarized signals from aerosol particles or cloud droplets with a $30 \mathrm{~m}$ vertical resolution and a $1 \mathrm{~min}$ average interval. We can acquire the 
accurate backscattering profile by means of a series of corrections (e.g., dead time, background signal, afterpulse, overlap, and range-corrected) according to the standard methods (Campbell et al., 2002). The detailed data acquisition and retrieval algorithms of the lidar system can be found in the publications of Campbell et al. (2002) and Z. Huang et al. (2010).

A weather transmitter (model WXT520, Vaisala, Finland) was set up on top of the SMF trailer to record the air temperature $\left(T\right.$ in $\left.{ }^{\circ}\right), \mathrm{RH}$, ambient pressure (P, unit: $\left.\mathrm{hPa}\right)$, wind speed, and wind direction at $10 \mathrm{~s}$ intervals. In this article, we calculated the $5 \mathrm{~min}$ and hourly averages from the raw data.

A dozen state-of-the-art broadband radiometers were installed in a row on a standard horizontal platform $(\sim 4 \mathrm{~m}$ above the surface) where the field of view was unobstructed in all directions (Bi et al., 2014). The direct normal irradiance and diffuse irradiance were independently measured by an incident pyrheliometer (model NIP, Eppley Lab.) and by a ventilated and shaded pyranometer (model PSP, Eppley Lab.), which were mounted on a two-axis automatic sun tracker (model 2AP, Kipp\&Zonen). The global irradiance $(0.285-2.8 \mu \mathrm{m})$ and downward longwave irradiance $(3.5-50 \mu \mathrm{m})$ were, respectively, gathered from a ventilated PSP pyranometer and a ventilated and shaded pyrgeometer (model PIR, Eppley Lab.). All irradiance quantities were stored in a Campbell data logger with 1 min resolution. Additionally, a Total Sky Imager (model TSI-880, YES Inc.) provides high-resolution sky pictures every minute during the daytime, which can detect and identify important weather conditions, such as dust storms, smoky pollution, and rainy, cloudy, or cloudless days.

\subsection{MERRA reanalysis products}

The MERRA (Modern-Era Retrospective Analysis for Research and Applications) reanalysis assimilates a variety of conventional observations (i.e., temperature, pressure, height, wind components) from surface weather stations, balloons, aircraft, ships, buoys, and satellites from 1980 to the present and is primarily committed to improving the hydrologic cycle and energy budget for the science community (Rienecker et al., 2011). In this paper, we utilized the 6hourly average wind fields at 500 and $850 \mathrm{hPa}$ levels from the MERRA reanalysis products.

\section{Results and discussion}

\subsection{Aerosol optical properties}

The aerosol SSA at $670 \mathrm{~nm}$ is defined as the ratio of the light scattering coefficient $\left(\sigma_{\mathrm{sp}, 670}\right)$ to the total extinction coefficient (the sum of $\sigma_{\mathrm{sp}, 670}$ and $\sigma_{\mathrm{ap}, 670}$ ). The SSA reflects the absorptive ability of aerosol particle and is a key quantity in determining the sign (warming or cooling) of aerosol radiative forcing for a certain underlying surface (Hansen et al., 1997; Ramanathan et al., 2001).
Figure 2 delineates the time series of hourly-averaged $\mathrm{PM}_{10}$ mass concentration, aerosol optical properties, and size distribution at Dunhuang farmland during the whole period. The overall mean, standard deviation, median, and different percentiles of aerosol optical properties are also tabulated in Table 2. Aerosol optical features exhibit dramatic day-to-day variations at Dunhuang. It is apparent that aerosol loadings in April and early May are systematically higher than those in late May and June, which agrees well with the results of columnar aerosol optical depths (AODs) derived from sky radiometer (Bi et al., 2014). This is chiefly attributed to the invading mineral particulates from the frequent occurrences of intense dust storms in spring. The highly unstable synoptic cyclones (i.e., Mongolian cyclone) are regularly hovering about northern China and Mongolia in springtime, which trigger high-frequency strong surface winds (Sun et al., 2001; Shao et al., 2011). The rising temperature in this season leads to the melting of frozen soil and snow cover, leaving behind a loose land surface and abundant bare soil sources, therefore creating favorable conditions for dust storms. In addition, the contributions of local dust emissions cannot be ignored. We have clearly recorded that there were numerous agricultural cultivation operations (e.g., land planning, plowing, and disking) throughout the Dunhuang farmland district from 1 April to 10 May, which produced a large amount of agricultural soil particles under strong winds and thus had a significant superimposed effect on elevated dust loading in the source and downwind regions prior to the growing season. Figure S1 in the Supplement also presents photographs of a variety of agricultural cultivations in Dunhuang farmland before the planting period, which supplies direct and powerful evidence to support our results. Those dust aerosols originated from disturbed soils induced by human activities and are interpreted as anthropogenic dust (Tegen and Fung, 1995). Recently, some investigators estimated that anthropogenic dust could account for approximately $25 \%$ of the global dust load (Ginoux et al., 2012; Huang et al., 2015), and more than $53 \%$ of the anthropogenic sources came from semi-arid and semi-wet zones (Huang et al., 2015; Guan et al., 2016). Nonetheless, it still remains a challenging task to distinguish between the natural and anthropogenic fractions of mineral dust by employing a single technology such as laboratory analysis, in situ measurements, model simulations, active, and passive remote sensing methods (e.g., multichannel lidar, sun-sky radiometer), which should be combined together (Bi et al., 2016). The overall mean $\mathrm{PM}_{10}$ concentration was $113 \pm 169 \mu \mathrm{g} \mathrm{m}^{-3}$ (mean \pm standard deviation), which is $\sim 39 \%$ lower than the $184.1 \pm 212 \mu \mathrm{g} \mathrm{m}^{-3}$ average level in Dunhuang $\left(40.1^{\circ} \mathrm{N}, 94.6^{\circ} \mathrm{E}, 1139 \mathrm{~m}\right)$ during the spring of 2004 (Yan, 2007) and $\sim 26 \%$ smaller than the value of $153 \pm 230 \mu \mathrm{g} \mathrm{m}^{-3}$ measured at Zhangye $\left(39.082^{\circ} \mathrm{N}\right.$, $100.276^{\circ} \mathrm{E}, 1460 \mathrm{~m}$ ) during spring of 2008 (Li et al., 2010). Wang et al. (2015) obtained a total average $\mathrm{PM}_{10}$ concentration of $172 \pm 180 \mu \mathrm{g} \mathrm{m}^{-3}$ at SACOL during late spring of 2007 (from 25 April to 25 June). The mean $\mathrm{PM}_{10}$ levels 
Table 2. Statistical summary of hourly-averaged aerosol optical properties measured during an intensive observation period ${ }^{\mathrm{a}}$.

\begin{tabular}{lrrrrrrr}
\hline Variable & Mean & $\mathrm{SD}^{\mathrm{b}}$ & Median & 10th percentile & 25th percentile & 75th percentile & 90th percentile \\
\hline $\mathrm{PM}_{10}\left(\mu \mathrm{g} \mathrm{m}^{-3}\right)$ & 113 & 169 & 54 & 17 & 29 & 111 & 300 \\
$\sigma_{\mathrm{sp}}\left(\mathrm{Mm}^{-1}\right)$ & 53.3 & 74.8 & 28.3 & 11.2 & 16.0 & 55.8 & 123.5 \\
$\sigma_{\mathrm{ap}}\left(\mathrm{Mm}^{-1}\right)$ & 3.20 & 2.40 & 2.50 & 1.27 & 1.69 & 3.90 & 5.94 \\
$\mathrm{SSA}(670 \mathrm{~nm})$ & 0.913 & 0.055 & 0.923 & 0.850 & 0.892 & 0.949 & 0.967 \\
$\mathrm{SAE}(450 / 700 \mathrm{~nm})$ & 0.45 & 0.45 & 0.42 & -0.1 & 0.1 & 0.73 & 0.99 \\
\hline
\end{tabular}

a All aerosol data reported for volumes under $1013.25 \mathrm{hPa}$ and $20^{\circ}$.

b SD denotes the standard deviation.

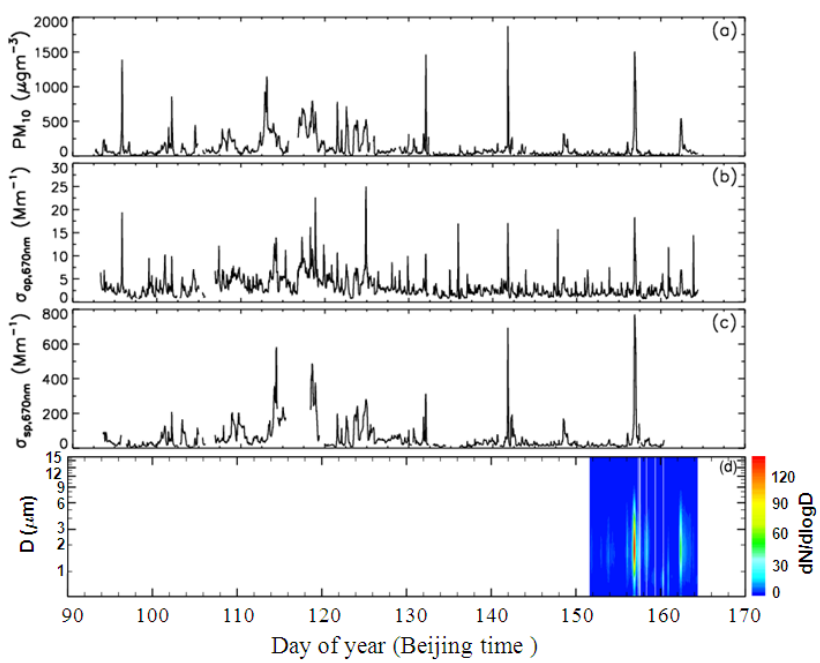

Figure 2. Time series of hourly-averaged (a) $\mathrm{PM}_{10}$ mass concentration in $\mu \mathrm{g} \mathrm{m}^{-3}$, (b) aerosol absorption coefficient at $670 \mathrm{~nm},(\mathbf{c})$ aerosol scattering coefficient at $670 \mathrm{~nm}$, and (d) aerosol size distribution in $\mathrm{cm}^{-3}$ at the Dunhuang farmland during the whole sampling period.

at Hunshan Dake sandland in northern China during spring of 2001 varied between 226 and $522 \mu \mathrm{g} \mathrm{m}^{-3}$ (Cheng et al., 2005).

The hourly-averaged aerosol $\sigma_{\mathrm{sp}, 670}$ was $53.3 \pm 74.8 \mathrm{Mm}^{-1}$. The large standard deviations of $\mathrm{PM}_{10}$ and $\sigma_{\mathrm{sp}}$ are possibly associated with the injection of dust particles during the intense dust storms. Our result was about a factor of 3 lower than the $\sigma_{\mathrm{sp}}$ at $500 \mathrm{~nm}$ in the other sites over northern China (i.e., $126 \pm 90 \mathrm{Mm}^{-1}$ for Dunhuang, $159 \pm 191 \mathrm{Mm}^{-1}$ for Zhangye, $164 \pm 89 \mathrm{Mm}^{-1}$ for SACOL). Despite a relatively small magnitude, $\sigma_{\mathrm{ap}, 670}$ also presented pronounced variations, with an average value and a maximum of $3.2 \pm 2.4$ and $25.0 \mathrm{Mm}^{-1}$, respectively. This result was a factor of 2 smaller than Yulin $\left(6 \pm 11 \mathrm{Mm}^{-1}\right.$; $\mathrm{Xu}$ et al., 2004) and a factor of 5-7 smaller than that at the Shangdianzi rural site $\left(17.5 \pm 13.4 \mathrm{Mm}^{-1}\right)$ in northern China (Yan et al., 2008) and Lin'an site $\left(\sim 23 \mathrm{Mm}^{-1}\right)$ in southern China (Xu et al., 2002). The mean light scattering and absorption coefficients in this study are comparable to the background levels $\left(\sim 46.9 \pm 16.9\right.$ and $\left.2.5 \pm 1.1 \mathrm{Mm}^{-1}\right)$ in the US Southern Great Plains (Delene and Ogren, 2002). This suggests that extremely low levels of light absorption and scattering substances are widely distributed throughout the Dunhuang region during the spring of 2012. Therefore, a little perturbation stemmed from human activities (e.g., agricultural cultivation, coal combustion from domestic heating and cooking, and biomass burning) would undoubtedly exert a considerable impact on the light absorption property.

A few strong dust episodes (4, 21-22, and 30 April, 1-3, $8-11$, and 20 May, 4 and 10 June, corresponding to DOY 95, $112-113,121,122-125,129-132,141,156$, and 162) could remarkably elevate the hourly-averaged values of $\mathrm{PM}_{10}$, $\sigma_{\mathrm{sp}}, \sigma_{\mathrm{ap}}$, and aerosol size distribution (see Fig. 2). During these dust events, the hourly $\mathrm{PM}_{10}$ concentrations generally exceeded $1000 \mathrm{\mu g} \mathrm{m}^{-3}$ and even approached $2000 \mu \mathrm{g} \mathrm{m}^{-3}$, which were 10 -fold greater than the overall mean level. The hourly $\sigma_{\mathrm{sp}}$ was more than $400 \mathrm{Mm}^{-1}$ or even close to $800 \mathrm{Mm}^{-1}$, and the corresponding $\sigma_{\mathrm{ap}}$ varied between 10 and $25 \mathrm{Mm}^{-1}$. Moreover, the peak values of aerosol number size distribution appear at the particle diameters of $1-3 \mu \mathrm{m}$, which was consistent with the result from remote sensing (Bi et al., 2014, 2016).

Figure 3 depicts the time evolutions of MPL normalized relative backscatter and depolarization ratio at Dunhuang farmland from 1 April to 12 June 2012. The depolarization ratio $(\delta)$ is a useful indication to discriminate between spherical particles ( $\delta$ of $\sim 0-0.1$ ) and nonspherical particles (mainly dust aerosol, $\delta>0.2$ ), since it is very sensitive to the nonsphericity of scattering particles (Kobayashi et al., 1985; Murayama et al., 1999; Shimizu et al., 2004; Huang et al., 2015). From Fig. 3 we can distinctly see that there was a dense dust layer below $4 \mathrm{~km}$ during the entire duration of the experiment, with the peak value centered on $1.0-1.5 \mathrm{~km}$, which was above the planetary boundary layer (PBL). The $\delta$ values commonly reached above $0.3(>\sim 0.3-0.5)$ during the heavy dust events and varied between 0 and 0.1 under clear-sky conditions (e.g., 6-7 April, 14-15 and 29 May, 9 June). 
(a) MPL normalized relative backscatter

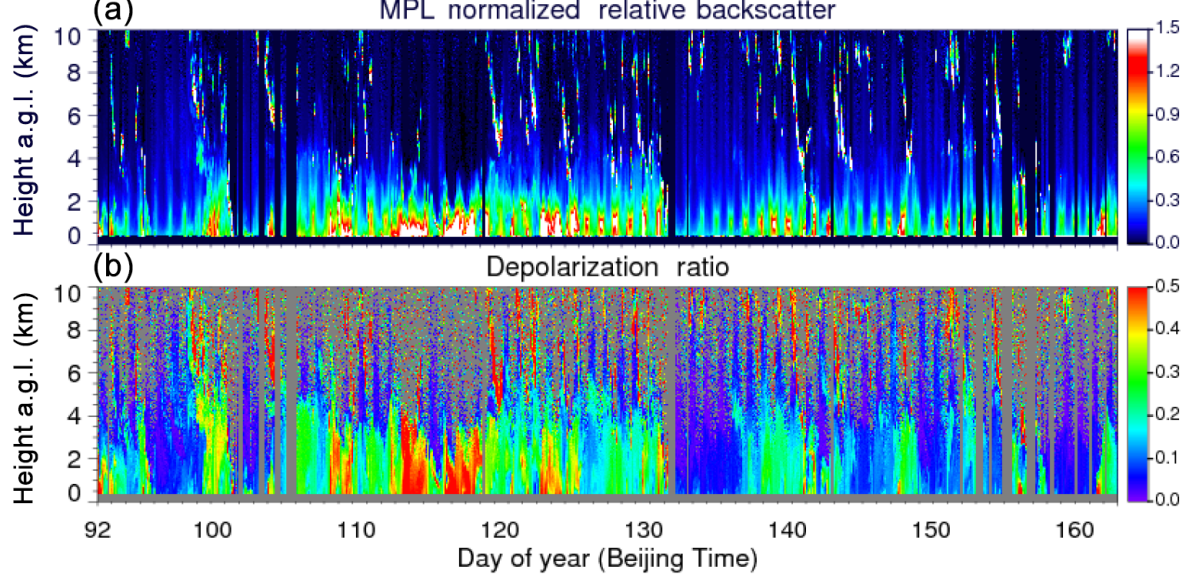

Figure 3. Time evolutions of the MPL normalized relative backscatter intensity (top panel) and depolarization ratio (bottom panel) at Dunhuang farmland from 1 April to 12 June 2012.
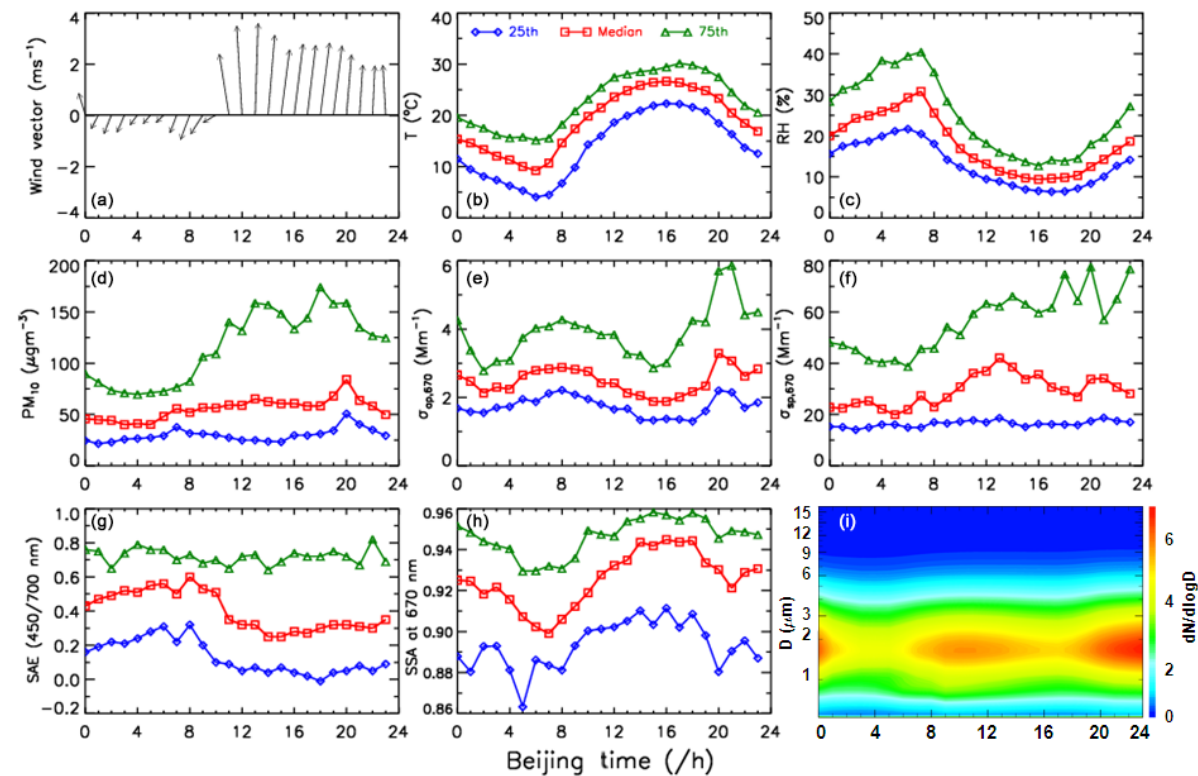

Figure 4. The diurnal variations of (first row, left to right) wind vector $\left(\mathrm{ms}^{-1}\right)$, air temperature $\left(T\right.$ in $\left.{ }^{\circ}\right)$, relative humidity $(\mathrm{RH}$ in $\%)$, (second row, left to right) $\mathrm{PM}_{10}$ concentration $\left(\mu \mathrm{g} \mathrm{m}^{-3}\right)$, aerosol scattering coefficient at $670 \mathrm{~nm}\left(\sigma_{\mathrm{sp}, 670}\right.$ in $\left.\mathrm{Mm}^{-1}\right)$, aerosol absorption

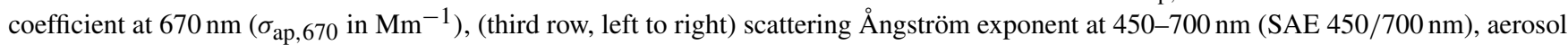
single-scattering albedo at $670 \mathrm{~nm}\left(\mathrm{SSA}_{670}\right)$, and aerosol size distribution $\left(\mathrm{d} N / \mathrm{d} \log D\right.$ in $\left.\mathrm{cm}^{-3}\right)$ at the Dunhuang site from 1 April to 12 June 2012 (30 May to 12 June for aerosol size distribution). Median values (red square) are shown to give a more apparent diurnal feature than mean values, which could be affected by several strong dust episodes. The 25 th (blue diamond) and 75 th (green triangle) percentiles for each hour of the day are also displayed.

\subsection{Diurnal variations}

Figure 4 illustrates the diurnal variations of wind vector $\left(\mathrm{ms}^{-1}\right)$, air temperature $\left(T\right.$ in $\left.{ }^{\circ}\right), \mathrm{RH}(\%), \mathrm{PM}_{10}\left(\mu \mathrm{g} \mathrm{m}^{-3}\right)$, $\sigma_{\mathrm{sp}, 670}\left(\mathrm{Mm}^{-1}\right), \sigma_{\mathrm{ap}, 670}\left(\mathrm{Mm}^{-1}\right)$, aerosol number size distribution $\left(\mathrm{d} N / \operatorname{dlog} D\right.$ in $\left.\mathrm{cm}^{-3}\right)$, SAE at $450-700 \mathrm{~nm}$, and SSA at $670 \mathrm{~nm}$ in Dunhuang farmland from 1 April to 12 June 2012. Note that the APS spectrometer was operated from 30
May to 12 June. A discernible wind vector was shown in the diurnal variation; in other words, strong southwest and south winds dominated in the daytime, from 11:00 to 24:00 LT (local time), and transformed into the weak northeast wind prevailed from the midnight to the following morning of 10:00 LT. The prominent phenomenon can be roughly interpreted by classical mountain-valley wind circulation, which was primarily generated by the diurnal differences of temper- 
ature between the mountain slope and the valley floor. During the daytime, the huge Beishan Mountain slope heats up by solar radiation more rapidly than the valley floor, which causes convection above the mountain slope. The compensating airflow is consequently directed toward the mountain slope, inducing upslope southerly wind or the valley wind, which usually peaks near midday and gradually disappears after sunset. Conversely, at night, radiative cooling of the mountain slope occurs more quickly than on the valley floor, inducing the mountain wind, which generally reaches maximum strength just before sunrise (Arya, 1999). Throughout the experiment, air temperature displayed a large diurnal variation (with the diurnal difference of $\delta T \sim 26^{\circ}$ ) and $\mathrm{RH}$ always kept below $40 \%$ for the whole day. It is very clear that the minimal $\mathrm{T}$ and maximal $\mathrm{RH}$ arose at around 06:0007:00 LT, and the maximal $T$ and minimal RH occurred at about 16:00 LT, which represented an energetic vertical turbulent motion in daytime and a stable radiative temperature inversion during nighttime.

The aerosol optical parameters also exhibited striking diurnal variations, which were closely related to the local meteorological elements. During the daytime (10:0018:00 LT), the $\mathrm{PM}_{10}$ concentration remained high level $\left(\sim 57-65 \mu \mathrm{g} \mathrm{m}^{-3}\right)$ and increased sharply from 19:00 LT and reached a maximum of $84.2 \mu \mathrm{g} \mathrm{m}^{-3}$ at 20:00 LT. The $\mathrm{PM}_{10}$ began to decrease from 21:00 LT until the next morning. A low level $\left(\sim 40-46 \mu \mathrm{g} \mathrm{m}^{-3}\right)$ was maintained at midnight (00:00-05:00 LT) and rose gradually from 06:00 LT and attained a secondary peak value of $55.7 \mu \mathrm{g} \mathrm{m}^{-3}$ at 07:00 LT. The aerosol light scattering $\left(\sigma_{\mathrm{sp}, 670}\right)$ presented a similar pattern with $\mathrm{PM}_{10}$, but the maximal value $\left(\sim 42 \mathrm{Mm}^{-1}\right)$ appeared at 13:00 LT, with the other two secondary peak values occurring at 20:00 $\left(\sim 34.1 \mathrm{Mm}^{-1}\right)$ and 07:00 LT $\left(\sim 27.3 \mathrm{Mm}^{-1}\right)$. The high levels of $\mathrm{PM}_{10}$ and $\sigma_{\text {sp }}$ during the daytime were primarily attributable to a strong south wind from Gobi and local dust emissions. By contrast, $\sigma_{\text {ap }, 670}$ showed a more pronounced diurnal feature, which proved to be mostly controlled by anthropogenic emissions ( $\mathrm{Li}$ et al., 2010). The diurnal $\sigma_{\text {ap }}$ always stayed at a low level $\left(\sim 2.0 \mathrm{Mm}^{-1}\right)$ from 13:00 to 18:00 LT and reached a maximum of $3.3 \mathrm{Mm}^{-1}$ at 20:00 LT. Subsequently, $\sigma_{\text {ap }}$ dramatically reduced from midnight and preserved at a low value of about $2.2 \mathrm{Mm}^{-1}$ from 02:00 to 04:00 LT and remained a steadily high level of $\sim 2.7-2.9 \mathrm{Mm}^{-1}$ from $05: 00$ to 10:00 LT. It can probably be explained as follows. The influences of local anthropogenic pollutants were commonly small in the afternoon, because the strong southerly wind from Gobi Desert and powerful daytime vertical convection mixing efficiently dilute local air pollutants. Because weak northeast wind and stable temperature inversion at night facilitate the accumulation of pollutants within the PBL, nighttime levels were normally larger. Increasing human activities (e.g., domestic cooking, traffic emissions for transportation and agriculture) in the early morning might also be responsible for the morning peaks in the aerosol absorption coef- ficient. The $\sigma_{\text {ap }}$ maximum at 20:00 LT was presumably influenced by the mixture of mineral dust and anthropogenic pollutants. This conclusion could be partly supported by the diurnal variation of SAE at $450-700 \mathrm{~nm}$ (Fig. 4), which showed high SAE values $(\sim 0.5-0.6)$ at 02:00-10:00 LT and low SAE values $(\sim 0.2-0.3)$ at 13:00-22:00 LT. Generally, a large SAE around 0.6 represents small particles (e.g., urbanpolluted aerosol or soot) and a small SAE less than 0.3 or a negative value corresponds to coarse-dominated large particles (e.g., dust or sea salt) (Anderson et al., 2003).

Furthermore, aerosol number size distribution exhibited a noticeably dominant supermicron particles the entire day, probably linked to the predominant dust aerosol in daytime and local anthropogenic emissions at nighttime. In this study, we postulated that the aerosol light extinction at the shortwave waveband is completely caused by those particles with aerodynamic diameters of $10 \mu \mathrm{m}$ or less. The mass scattering efficiency is designated as the ratio of $\sigma_{\mathrm{sp}}$ to $\mathrm{PM}_{10}$ concentration. Therefore, the mass scattering efficiency for $\mathrm{PM}_{10}$ aerosols was about $0.67 \mathrm{~m}^{2} \mathrm{~g}^{-1}$ in the afternoon and $\sim 0.77 \mathrm{~m}^{2} \mathrm{~g}^{-1}$ in the morning $(\sim 0.25$ for heavy dust events and $\sim 0.70$ for the whole period). Our results were slightly less than $\sim 1.05 \mathrm{~m}^{2} \mathrm{~g}^{-1}$ in Dunhuang during spring of 2004 (Yan, 2007). Similarly, the mass absorption efficiency was $\sim 0.017 \mathrm{~m}^{2} \mathrm{~g}^{-1}$ under heavy dust episodes and $\sim 0.08 \mathrm{~m}^{2} \mathrm{~g}^{-1}$ in the morning, which was coincident with the laboratory analytical result of natural desert aerosol at $660 \mathrm{~nm}\left(\sim 0.01-0.02 \mathrm{~m}^{2} \mathrm{~g}^{-1}\right)$ in the Ulan Buh Desert $\left(39^{\circ} 26^{\prime} \mathrm{N}, 105^{\circ} 40^{\prime} \mathrm{E}\right)$ of northern China (Alfaro et al., 2004). These diurnal variations of the mass scattering and absorption efficiencies likely reflect the changes in aerosol chemical composition. The SSA at $670 \mathrm{~nm}$ displayed distinct differences between daytime and nighttime (Fig. 4), and the two minimal values at 07:00 LT $(\sim 0.90)$ and 20:00 LT $(\sim 0.921)$ were consistent with the aforementioned $\sigma_{\mathrm{ap}, 670}$ diurnal feature. The peak values of SSA $(0.945 \pm 0.04)$ for dominant dust particles in the afternoon agreed well with other field campaigns in Zhangye $(0.95 \pm 0.02$; Li et al., 2010) and Yulin $(0.95 \pm 0.04$; Xu et al., 2004). The daily low SSA (0.90-0.92) or overall mean of $0.913 \pm 0.055$ at Dunhuang was still bigger than that in both urban $(0.81$; Bergin et al., 2001) and rural (0.81-0.85; Li et al., 2007) regions adjacent to Beijing, presumably ascribed to dust particles at night. Yan et al. (2008) conducted 2-year long field measurements at Shangdianzi Global Atmosphere Watch (GAW) rural site in northern China $(\sim 150 \mathrm{~km}$ from Beijing) and estimated a mean SSA of $0.88 \pm 0.05$, but their data contained summer when aerosol scattering coefficients may be strengthened by hygroscopic growth and secondary chemical process.

The wind rose plots give a further insight into the linkages between the meteorological factors and pollutants, as described in Fig. 5. In the morning (06:00-09:00 LT), a marked northeast wind was prevalent and wind speed was mostly less than $4 \mathrm{~ms}^{-1}$, which revealed that emissions were primarily descended from nearby farmlands and rural residences 

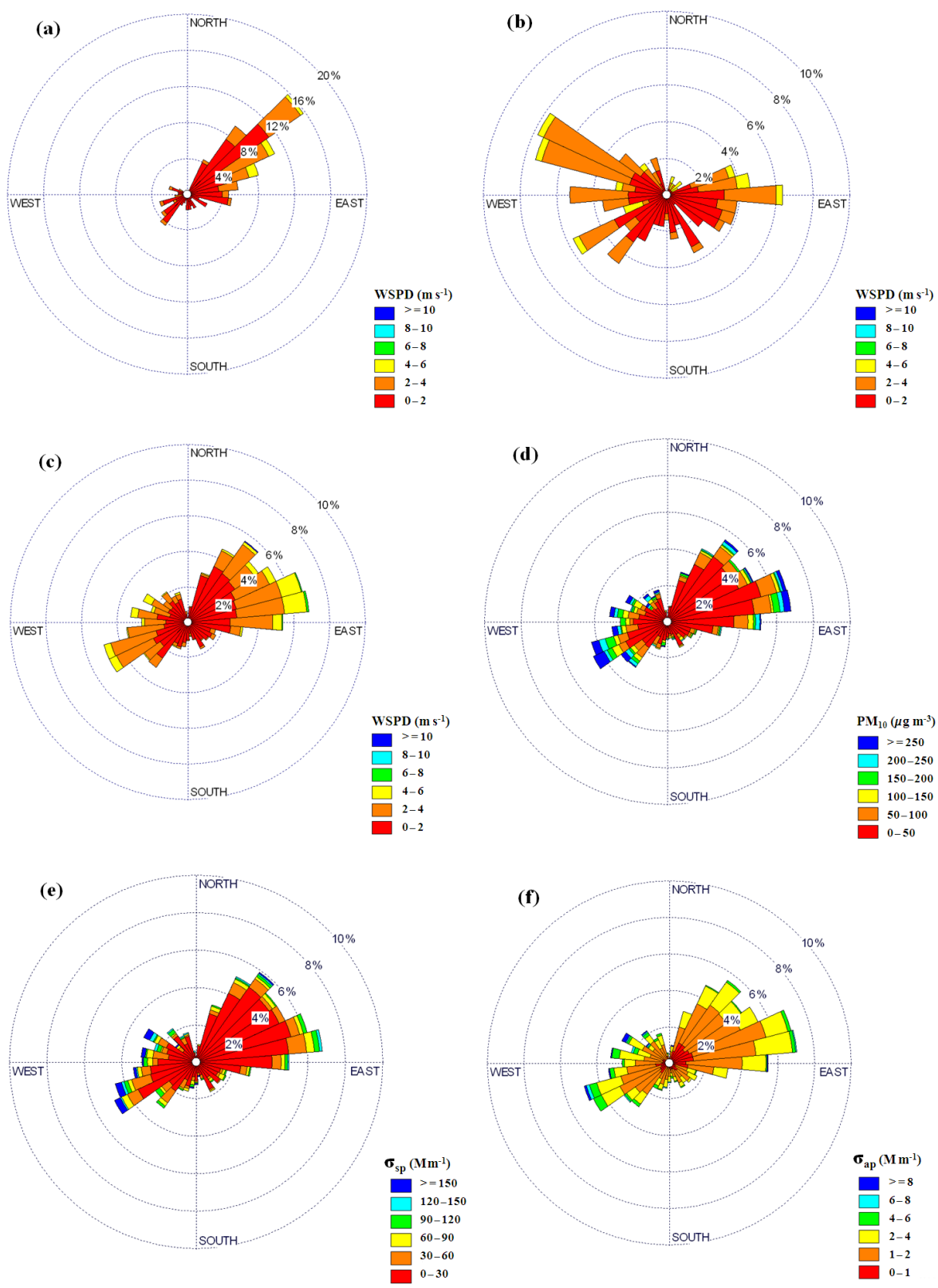

Figure 5. Wind rose plots for (a) morning (06:00-09:00 LT), (b) evening (19:00-22:00 LT), and (c) all hours; shade represents wind speed $\left(\mathrm{ms}^{-1}\right)$. Wind roses for all hours, with shade representing levels of (d) $\mathrm{PM}_{10}$ concentration $\left(\mu \mathrm{g} \mathrm{m}^{-3}\right)$, (e) aerosol scattering coefficient at $670 \mathrm{~nm}\left(\sigma_{\mathrm{sp}}\right.$ in $\left.\mathrm{Mm}^{-1}\right)$, and (f) aerosol absorption coefficient at $670 \mathrm{~nm}\left(\sigma_{\mathrm{ap}}\right.$ in $\left.\mathrm{Mm}^{-1}\right)$.

(Fig. 5a). Although a prominent northwest wind mainly occurred in the evening hours (19:00-22:00 LT), the east wind and southwest wind also appeared, which indicated that anthropogenic pollution came from both local sources and a relatively large region along the valley (Fig. 5b). Additionally, Fig. 5c showed the predominant winds were northeast and southwest winds in Dunhuang area, with the maximal hourly-averaged wind speed exceeding $10 \mathrm{~ms}^{-1}$. It was very clear that the southwest and northwest winds created higher levels of $\mathrm{PM}_{10}$ mass concentration $\left(>250 \mu \mathrm{g} \mathrm{m}^{-3}\right.$ ), aerosol light scattering coefficient $\left(\sigma_{\mathrm{sp}}>150 \mathrm{Mm}^{-1}\right)$, and absorption coefficient $\left(\sigma_{\mathrm{ap}}>8 \mathrm{Mm}^{-1}\right)$, whereas northeast wind generated slightly smaller concentrations of $\mathrm{PM}_{10}(\sim 50$ $\left.100 \mu \mathrm{g} \mathrm{m}^{-3}\right), \sigma_{\mathrm{sp}}\left(\sim 30-60 \mathrm{Mm}^{-1}\right)$, and $\sigma_{\text {ap }}\left(\sim 2-4 \mathrm{Mm}^{-1}\right)$. This possibly implies that southwest and northwest winds may bring about dust particles and northeast wind may transport the air pollutants. 


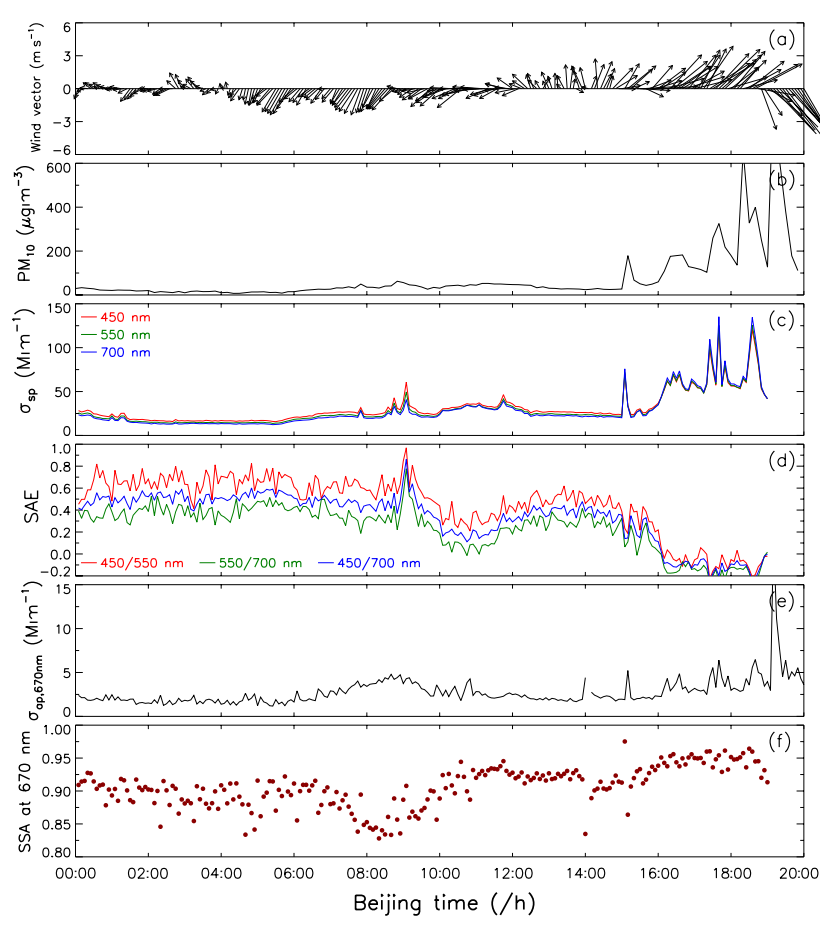

Figure 6. Time series of (a) wind vector $\left(\mathrm{ms}^{-1}\right)$; (b) $\mathrm{PM}_{10}$ concentration $\left(\mu \mathrm{g} \mathrm{m}^{-3}\right)$; (c) aerosol scattering coefficient $\left(\sigma_{\mathrm{sp}}\right.$ in $\left.\mathrm{Mm}^{-1}\right)$ at $450 \mathrm{~nm}$ (red), $550 \mathrm{~nm}$ (green), and $700 \mathrm{~nm}$ (blue); (d) scattering Ångström exponent (SAE) at 450-550 nm (red), 550-700 nm (green), and 450-700 nm (blue); (e) aerosol absorption coefficient at $670 \mathrm{~nm}\left(\sigma_{\mathrm{ap}}\right.$ in $\left.\mathrm{Mm}^{-1}\right)$; and (f) single-scattering albedo at $670 \mathrm{~nm}$ (SSA 670 ) during a typical Tomb-Sweeping Day on 4 April 2012, which implies a potential anthropogenic influence on aerosol optical properties. All data points are obtained from 5 min average values.

\subsection{Local anthropogenic emission sources}

As mentioned previously, crop residue burning and agricultural cultivated operations before the growing season could produce local emission source proximity to the study area. Also, sporadic straw burning occurred throughout the Dunhuang farmland from 1 April to 10 May 2012, which was the major source of black carbon surrounding the site. To clarify the potential anthropogenic influence on aerosol optical properties in desert region, we investigated a typical biomass burning event.

Figure 6 outlines the time series of $5 \mathrm{~min}$ average wind vector $\left(\mathrm{ms}^{-1}\right), \mathrm{PM}_{10}\left(\mu \mathrm{g} \mathrm{m}^{-3}\right), \sigma_{\mathrm{sp}}$ at 450,550 , and $700 \mathrm{~nm}$ $\left(\mathrm{Mm}^{-1}\right), \operatorname{SAE}(450-550,550-700$, and $450-700 \mathrm{~nm}), \sigma_{\mathrm{ap}, 670}$ $\left(\mathrm{Mm}^{-1}\right)$, and SSA at $670 \mathrm{~nm}$ during a typical TombSweeping Day on 4 April 2012. Tomb-Sweeping Day is a traditional Chinese festival for sacrificial rites, in commemoration of dead ancestors. To pay homage to loved ones, people burn joss sticks, candles, and paper offerings and set off firecrackers on that day throughout China, which emits a large amount of air pollutants, such as biomass burning aerosol, sulfur dioxide, organic matter, and fugitive dust.
From Fig. 6a we see that slight and variable winds (with wind speed $<4 \mathrm{~ms}^{-1}$ ) mainly came from the northeast from 00:00 to 12:00 LT and abruptly changed into weak southeast wind and south wind; finally, gradually intensified southwest winds $\left(>10 \mathrm{~ms}^{-1}\right)$ became dominant and triggered a severe dust storm from 15:00 LT to the midnight. Prior to the occurrence of dust episode, the aerosol optical characteristics stayed stable, but a moderate increase was evident from 08:00 to 10:00 LT. For instance, $\mathrm{PM}_{10}$ concentration gradually increased from background level $\sim 30 \mu \mathrm{g} \mathrm{m}^{-3}$ to a maximum of $62.5 \mu \mathrm{g} \mathrm{m}^{-3}$ at about 09:00 LT, $\sigma_{\mathrm{sp}, 550}$ from $\sim 15$ to $49.6 \mathrm{Mm}^{-1}$, and $\sigma_{\mathrm{ap}, 670}$ from $\sim 2.0$ to $4.75 \mathrm{Mm}^{-1}$. This is ascribed to the contribution of biomass burning from ritual activities during Tomb-Sweeping Day. The SAE value at $450-700 \mathrm{~nm}$ remained invariant $(\sim 0.50)$ before 08:00 LT and sharply rose to a maximal value of 0.87 at 09:00 LT, afterwards gently reducing to around 0.4 , which indicated that the fine-mode particles (i.e., black carbon or soot) were dominated from 08:00 to 10:00 LT. The SAEs at various wavelengths systematically decreased from 0.4 at 15:00 LT to -0.25 at midnight, suggesting the dust-dominant coarsemode particles were prevailed. Meanwhile, the lidar depolarization ratio $(\delta)$ also further verified the existence of small size soot particle. The $\delta$ value remained steady at $0.15-0.20$ during 08:00 to 10:00 LT, rapidly increased to above 0.3 from 15:00 LT onwards, and even approached 0.50 during intense dust storm (see Fig. 3). The diurnal variation of $\mathrm{SSA}_{670}$ showed a more prominent feature, as illustrated in Fig. 6f. The SSA $_{670}$ values remained between 0.88 and 0.92 during 00:00 to 07:00 LT and dramatically reduced to a minimum of $\sim 0.83$ at 08:30-09:00 LT, then rose to 0.925 , confirming the very striking impacts by light absorbing substances. After 15:00 LT, the $\mathrm{SSA}_{670}$ gradually increased and reached up to about 0.96 during dust storms occurred. Bi et al. (2014) demonstrated that dust aerosols shortwave radiative forcing at the top of the atmosphere was a warming effect when $\mathrm{SSA}_{500}$ was less than 0.85 but was a cooling effect when $\mathrm{SSA}_{500}$ was greater than 0.85 for the Dunhuang/Gobi Desert area with high surface albedo. Therefore such significant anthropogenic influence would clearly modify the microphysical and chemical properties of dust aerosols and eventually exert remarkable impacts on environmental quality and climatic forcing of dust particle on both local and regional scales.

\subsection{Dust case study}

In this section, we explored the absorptive and optical characteristics of mineral dust during several typical dust cases and discussed its influence on Earth's radiation balance. Figure 7 provides the wind fields at 500 and $850 \mathrm{hPa}$ levels during three heavy dust events, based on MERRA reanalysis products. Note that Dunhuang farmland is marked with a red star and the white areas at $850 \mathrm{hPa}$ represent the missing values. It is evident that the East Asian region was governed by 

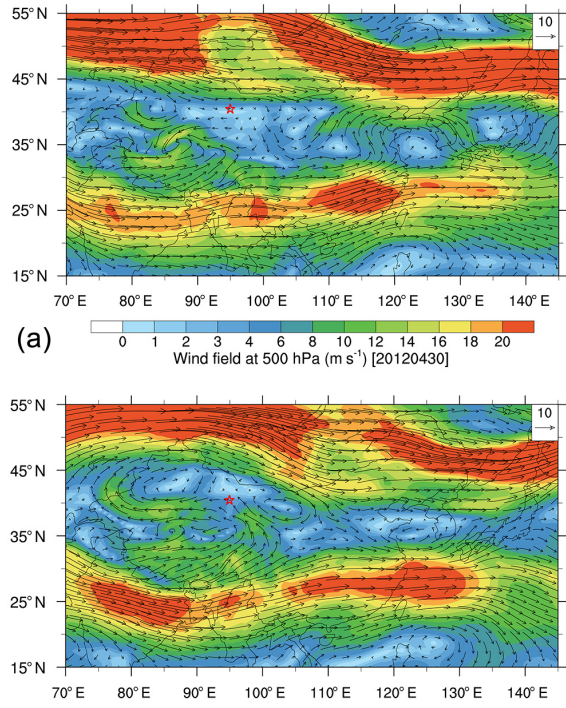

(c)
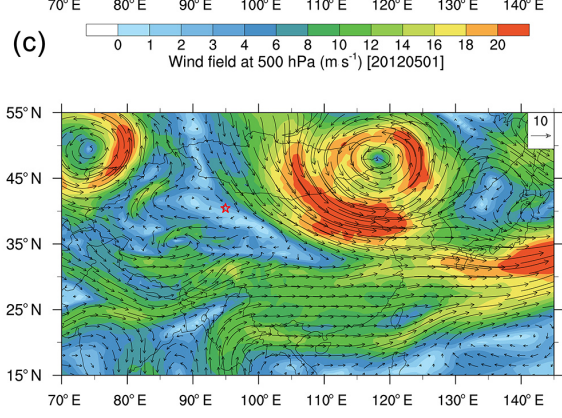

(e) $\begin{array}{llllllll}70^{\circ} \mathrm{E} & 80^{\circ} \mathrm{E} & 90^{\circ} \mathrm{E} & 100^{\circ} \mathrm{E} & 110^{\circ} \mathrm{E} & 120^{\circ} \mathrm{E} & 130^{\circ} \mathrm{E} & 140^{\circ} \mathrm{E}\end{array}$

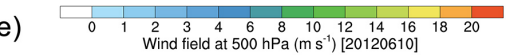
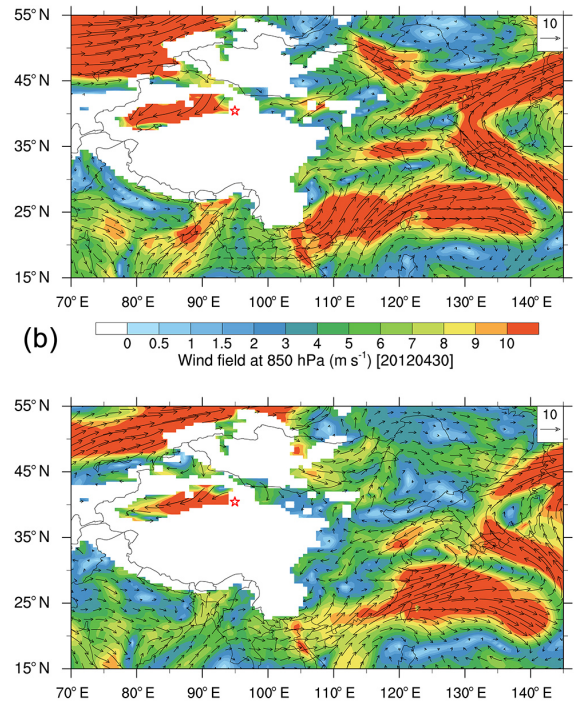

(d)
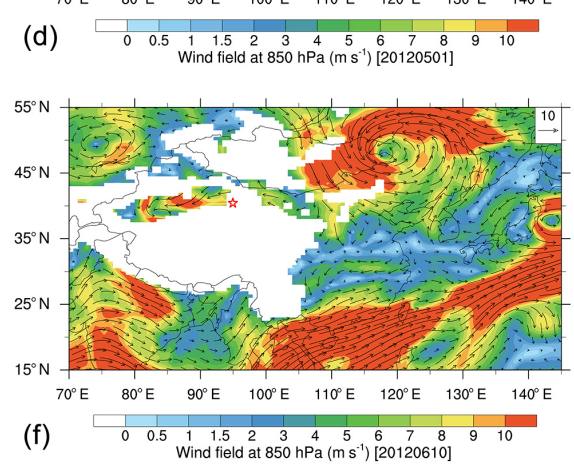

Figure 7. The wind fields (black arrows) at $500 \mathrm{hPa}$ (left panel) and $850 \mathrm{hPa}$ (right panel) levels during three heavy dust events on 30 April (top), 1 May (middle), and 10 June (bottom) 2012, based on MERRA reanalysis data. Note that the Dunhuang farmland is marked with a red star and the white regions at $850 \mathrm{hPa}$ are on behalf of the missing values.

the powerful and stable westerlies at a height of $500 \mathrm{hPa}$ on 30 April and 1 May 2012, whereas two very strong synoptic cyclones at a height of $500 \mathrm{hPa}$ hovered about the Mongolia and Kazakhstan on 10 June 2012, matching up with corresponding cyclone systems appearing at the $850 \mathrm{hPa}$ level. Although there were missing data in most of northwest China, extremely intense northeast wind and east wind $\left(>10 \mathrm{~ms}^{-1}\right)$ at $850 \mathrm{hPa}$ level prevailed over the northern territory of Xinjiang Uyghur Autonomous Region during the selected dust storms, which was close to the Dunhuang site. This could be confirmed by the simultaneous observations of wind speed and wind direction near the surface at Dunhuang farmland, as delineated in Fig. 8a. The measured strong northeast and east winds always dominated in Dunhuang and 5 min average wind speed were attained above $10 \mathrm{~ms}^{-1}$ during intense dust episodes. The selected three dust processes regularly lasted for several hours during daytime (e.g., from 10:00 to 18:00 LT) and the dust event on 1 April persisted until midnight, which contributed massive dust particles into the atmosphere.
There were no measurements of aerosol scattering coefficient $\left(\sigma_{\mathrm{sp}}\right)$ on 10 June due to equipment failure. From Fig. 8, we see that $\mathrm{PM}_{10}$ concentrations usually exceeded $400 \mu \mathrm{g} \mathrm{m}^{-3}$ and even reached up to $1000 \mu \mathrm{g} \mathrm{m}^{-3}$ during the heavy dust storms, and corresponding $\sigma_{\mathrm{sp}, 550}$ and $\sigma_{\mathrm{ap}, 670} \mathrm{val}-$ ues were generally more than 100 and $5 \mathrm{Mm}^{-1}$, respectively, or approached 350 and $15 \mathrm{Mm}^{-1}$ in our case. It is worth noting that even though pure dust aerosol possesses relatively low light-absorption ability (with mass absorption efficiency at $660 \mathrm{~nm}$ of $\sim 0.01-0.02 \mathrm{~m}^{2} \mathrm{~g}^{-1}$ ), the injection of plentiful mineral particles from dust episodes led to considerably high values of $\sigma_{\mathrm{ap}, 670}$. The SAEs at diverse wavelengths commonly kept at 0.50 or more during non-dust conditions, while corresponding values dramatically reduced to $-0.25-0$ under heavy dust cases, which is taken for granted. The $\mathrm{SSA}_{670}$ also exhibited apparent diurnal variations in Fig. 8f. The SSA670 values regularly preserved between 0.88 and 0.92 at nighttime or non-dust weather and gradually increased to a maximum of $\sim 0.96-0.98$ during strong dust processes, which were close to the measured value of $\sim 0.97-0.99$ for nearly pure Asian dust particles (Anderson et al., 2003; Bi et al., 


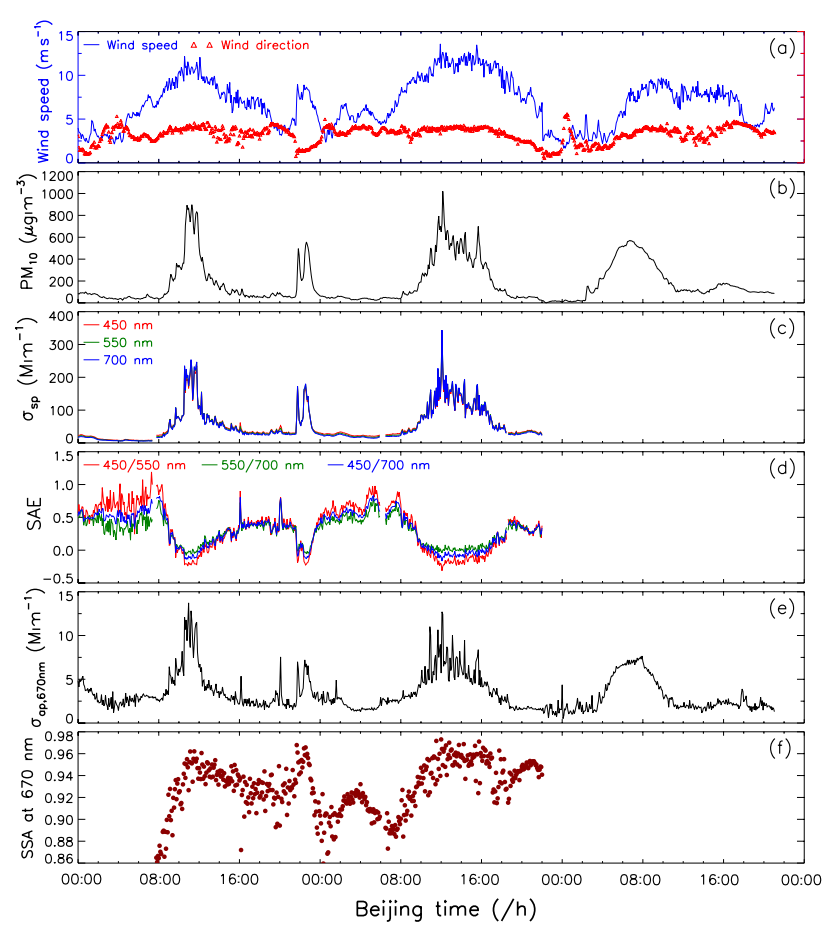

Figure 8. The same as Fig. 6, except for (a) wind speed $\left(\mathrm{ms}^{-1}\right)$ and wind direction $\left(^{\circ}\right)$ during three heavy dust events on 30 April, 1 May, and 10 June 2012. There were no measurements of aerosol scattering coefficient $\left(\sigma_{\mathrm{sp}}\right.$ in $\left.\mathrm{Mm}^{-1}\right)$ on 10 June due to equipment failure.

2016). These abundant mineral particles in desert source regions were very likely mixed with local air pollutants, especially at night, when the anthropogenic pollution favorably built up within the PBL. Moreover, airborne dust particles ordinarily traveled long distances to downstream areas via synoptic cyclones, which would deteriorate the ambient air quality and affected atmospheric chemistry and climate change on a regional scale.

Figure 9 describes the column-integrated AOD at five wavelengths $(400,500,675,870$, and $1018 \mathrm{~nm})$ versus Ångström exponent $(\alpha)$ at $400-870 \mathrm{~nm}$ on two completely clear-sky days (14 May and 9 June) and two typical dusty days (30 April and 10 June), which were acquired from a sky radiometer (model POM-01, PREDE Co. Ltd.). The sky radiometer can measure the direct solar irradiances and sky diffuse radiances at narrow spectral wavebands during daytime with 10 min interval. The columnar aerosol optical properties under cloudless conditions were retrieved from sophisticated inversion algorithms (Nakajima et al., 1996). Note that the cloud-contaminated datasets have been eliminated by means of a series of cloud-screening procedures developed by Khatri and Takamura (2009). From Fig. 9, all AOD values under clear-sky days kept very stable variations throughout the day and ranged from 0.02 to 0.12 , which was comparable to the clean background levels in the central Tibetan Plateau (Xia et al., 2011) and Badain Jaran Desert (Bi et al., 2013). The corresponding Ångström exponent $\alpha$ on 14 May and 9 June were greater than 0.6 , indicating extremely low aerosol loading. In contrast, the AODs under dust events (30 April and 10 June) displayed pronounced diurnal variations and all AOD values were larger than 0.30 (with maximum of 0.60 ), and $\alpha$ varied between 0.10 and 0.25 , representing high dust concentration levels. These elevated dust particles in the atmosphere would readjust the energy distributions of solar radiative fluxes at the surface.

Based on aforementioned measurements of the Total Sky Imager, micro-pulse lidar, and sky radiometer, we identified three completely clear-sky days (14 May, 29 May, and 9 June) and two "clean" dusty days (30 April and 10 June). The "clean" dusty days in this study were denoted as the dust storms weather without the influence of clouds. This afforded us a good opportunity to elucidate the potential impacts of dust events on radiation balance at the ground. Figure 10 draws the 1 min average solar direct normal radiation, sky diffuse radiation, total shortwave radiation, and downward longwave radiation fluxes under the selected 5 days, which were derived from the high-precision broadband radiometers as described in Sect. 2.3. All radiative quantities presented smooth diurnal variations under clear-sky cases (14 May, 29 May, and 9 June). The airborne dust particles impeded the sunlight to the ground through scattering and absorbing solar radiation; for instance, they significantly reduced the surface direct radiative fluxes in daytime to about $200-350 \mathrm{Wm}^{-2}$ (Fig. 10a) but considerably increased the surface diffuse radiative fluxes up to $\sim 150-300 \mathrm{Wm}^{-2}$ (Fig. 10b). As a result, the overall attenuation effect on total shortwave radiative fluxes varied between -150 and $-50 \mathrm{Wm}^{-2}$. The incoming solar energy absorbed by dust particles would heat the atmospheric dust layer (Bi et al., 2014) that likely played a profound role in the structure of atmospheric boundary layer and cloud microphysical process (J. Huang et al., 2006, 2010; Li et al., 2016). The downward longwave radiation (DLW) at the surface was majorly reliant on the clouds, water vapor, $\mathrm{CO}_{2}$, and other greenhouse gases (Wang and Dickinson, 2013). In general, the presence of clouds in the atmosphere would drastically affect the diurnal variation of DLW. The smooth changes of DLW under both clear-sky and dusty days in Fig. 10d revealed the robustness of the cloud screening method used in this paper. Figure 10d shows that the DLW values in dusty cases were always greater than in clear-sky cases, with the total average differences of $+40-+60 \mathrm{Wm}^{-2}$. The warming dust layer could enhance the surface DLW; hence the dust particles should contribute a large percentage to the increased DLW, but not all. This is because the potential water vapor in the atmosphere could substantially affect the DLW variations. For instance, the DLW on 9 June was distinctly greater than in other cloudless cases (i.e., 14 and 29 May) and the dusty case of 30 April. It is partly attributable to the higher RH values on 9 June than on other days, as shown in Fig. S2. 

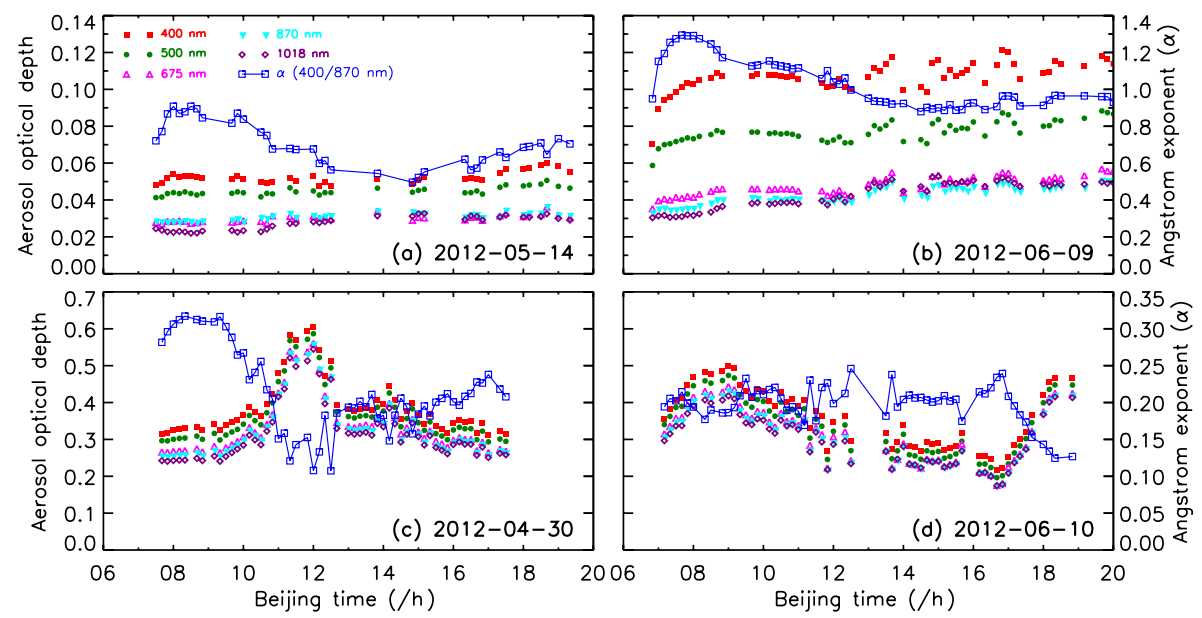

Figure 9. Time evolutions of aerosol optical depth (AOD) at five wavelengths (400, 500, 675, 870, and $1018 \mathrm{~nm})$ versus Ångström exponent $(\alpha)$ at 400-870 nm on (a) 14 May, (b) 9 June, (c) 30 April, and (d) 10 June 2012. Note that (a)-(b) are adopted from Bi et al. (2014) with an addition of the Ångström exponent plot in the original publication.
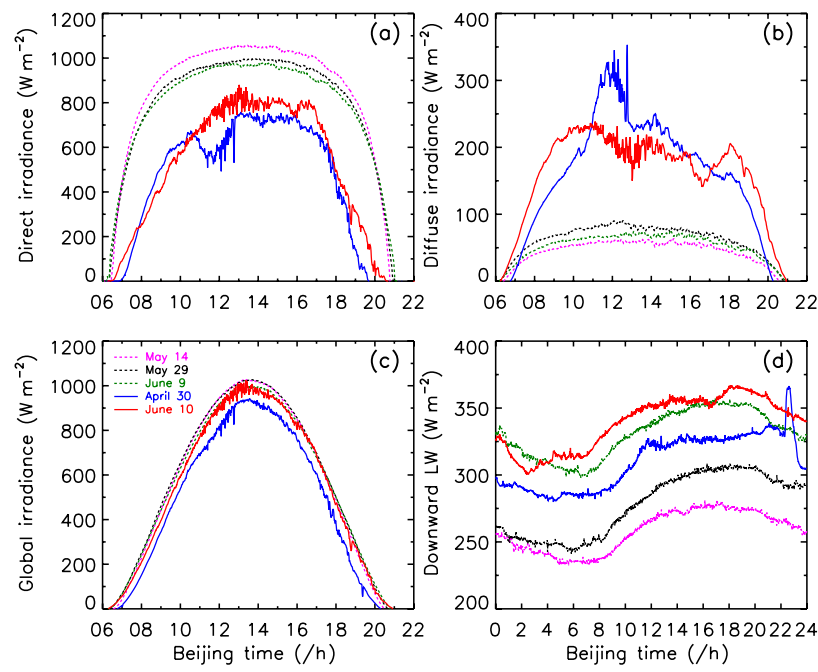

Figure 10. Diurnal variations of ground-based measurements of 1 min average (a) direct, (b) diffuse, and (c) global irradiances, and (d) downward longwave irradiance under completely clear-sky conditions (14 May, 29 May, and 9 June) and dust events (30 April and 10 June).

\section{Concluding remarks}

In this article, we surveyed the optical features and size distribution of dust aerosol in a Gobi farmland region of northwest China from 1 April to 12 June 2012 and uncovered a potential anthropogenic influence. The overall average $\mathrm{PM}_{10}$ mass concentration, light scattering coefficient $\left(\sigma_{\mathrm{sp}, 670}\right)$, absorption coefficient $\left(\sigma_{\mathrm{ap}, 670}\right)$, and singlescattering albedo ( $\left.\mathrm{SSA}_{670}\right)$ throughout the experiment were $113 \pm 169 \mu \mathrm{g} \mathrm{m}^{-3}, 53.3 \pm 74.8 \mathrm{Mm}^{-1}, 3.2 \pm 2.4 \mathrm{Mm}^{-1}$, and $0.913 \pm 0.05$, which were comparable to the background levels in the southern United States but lower than those in eastern and other northwestern Chinese cities. Frequent dust storms could markedly elevate dust loading and dominated the temporal evolution of airborne aerosol in the Dunhuang region. The hourly-averaged $\mathrm{PM}_{10}, \sigma_{\mathrm{sp}, 670}$, and $\sigma_{\mathrm{ap}, 670}$ reached up to $2000 \mathrm{\mu g} \mathrm{m}^{-3}, 800 \mathrm{Mm}^{-1}$, and $25 \mathrm{Mm}^{-1}$ during the severe dust events that were 10 -fold greater than the total mean values, along with the peak values of aerosol number size distribution appearing at the particle diameters 1$3 \mu \mathrm{m}$. Meanwhile, the correspondingly high $\mathrm{SSA}_{670}(\sim 0.96-$ 0.98 ) and depolarization ratio ( $\delta$ of $\sim 0.3-0.5$ ) and low SAE $(-0.25-0)$ values adequately verified the presence of coarsemode mineral dust, resulting in significantly reduced solar direct radiation $\left(\sim 200-350 \mathrm{Wm}^{-2}\right)$ and increased diffuse radiation $\left(\sim 150-300 \mathrm{Wm}^{-2}\right)$ at the surface, thus affecting the regional climate.

Due to relatively low aerosol levels observed in Dunhuang, any slightly anthropogenic perturbation would induce a substantial influence on the aerosol physicochemical property. The so-called anthropogenic dust produced by agricultural cultivating operations (e.g., land planning, plowing, and disking) brought a significant superimposed effect on high dust concentrations in Dunhuang farmland prior to the growing season, when the underlying surface was primarily covered with bare soils. This could to some extent be interpreted as the drastic changes of aerosol loadings in April and early May. In contrast, the local pollutant emissions mainly affected the absorptive characteristics of dust aerosol especially at night, when the anthropogenic pollutants favorably accumulated within the PBL and likely mixed with abundant mineral dust in the atmosphere. Therefore, the diurnal variations of $\sigma_{\mathrm{ap}, 670}$ and $\mathrm{SSA}_{670}$ exhibited prominent features, both of which have two peak values at night and in the early morning. For instance, $\sim 3.3 \mathrm{Mm}^{-1}$ at 20:00 LT and 
$\sim 2.9 \mathrm{Mm}^{-1}$ at 08:00 LT for $\sigma_{\mathrm{ap}, 670}$ were much higher than the low level of $\sim 2.0 \mathrm{Mm}^{-1}$ in the afternoon, which was attributed to the influence of anthropogenic emissions. The mean $\mathrm{SSA}_{670}$ of predominant dust particles in the afternoon (13:00-18:00 LT) was $0.945 \pm 0.04$, which was evidently greater than the mixed dust-pollutant-dominated $\mathrm{SSA}_{670}$ of $\sim 0.90$ at 07:00 LT and $\sim 0.92$ at 20:00 LT.

The findings of this study directly demonstrated that mineral dust in Dunhuang farmland was substantially affected by anthropogenic pollutants, which may provide further insight into the interaction of dust aerosol, atmospheric chemistry, and regional climate in desert source regions. However, the potentially anthropogenic influences on dust aerosol in Dunhuang were much smaller than that measured in eastern China, which was expected for remote desert areas with sparse populations and fewer human activities. Recently, Huang et al. (2016) indicated that most of the drylands in the world were fragile and susceptible to climate change and human activities and would be subject to the acceleration of drought expansion by the end of 21 st century. Under the possible scenario, it is critical to make clear the relative contributions of natural and anthropogenic forcing factors on global climate change, such as natural dust and anthropogenic dust, which calls for further investigation through a lot more observations and technological development.

Data availability. All ground-based aerosol datasets used in this paper are available by contacting Jianrong Bi (bijr@lzu.edu.cn).

\section{The Supplement related to this article is available online at https://doi.org/10.5194/acp-17-7775-2017-supplement.}

Competing interests. The authors declare that they have no conflict of interest.

Acknowledgements. This work was jointly supported by the Foundation for Innovative Research Groups of the National Natural Science Foundation of China (41521004), the National Natural Science Foundation of China (41575015 and 41405113), the Fundamental Research Funds for the Central Universities lzujbky-2015-4 and lzujbky-2016-k01, and the China 111 Project (no. B 13045). The authors would like to express special thanks to David S. Covert for guiding the in situ aerosol measurements. We thank the OMI and MERRA teams for supplying the satellite data and reanalysis products used in this study. We also appreciate all anonymous reviewers for their insightful and valuable comments.

Edited by: Aijun Ding

Reviewed by: two anonymous referees

\section{References}

Alfaro, S. C., Lafon, S., Rajot, J. L., Formenti, P., Gaudichet, A., and Maillé, M.: Iron oxides and light absorption by pure desert dust: An experimental study, J. Geophys. Res., 109, D08208, https://doi.org/10.1029/2003JD004374, 2004.

Anderson, T. L. and Ogren, J. A.: Determining aerosol radiative properties using the TSI 3563 Integrating Nephelometer, Aerosol Sci. Technol., 29, 57-69, https://doi.org/10.1080/02786829808965551, 1998.

Anderson, T. L., Covert, D. S., Marshall, S. F., Laucks, M. L., Charlson, R. J., Waggoner, A. P., Ogren, J. A., Caldow, R., Holm, R. L., Quant, F. R., Sem, G. J., Wiedensohler, A., Ahlquist, N. A., and Bates, T. S.: Performance characteristics of a high-sensitivity, three-wavelength total scatter-backscatter nephelometer, J. Atmos. Ocean. Technol., 13, 967-986, 1996.

Anderson, T. L., Masonis, S. J., Covert, D. S., Ahlquist, N. C., Howell, S. G., Clarke, A. D., and McNaughton, C. S.: Variability of aerosol optical properties derived from in situ aircraft measurements during ACE-Asia, J. Geophys. Res., 108, 8647, https://doi.org/10.1029/2002JD003247, 2003.

Aoki, I., Kurosaki, Y., Osada, R., Sato, T., and Kimura, F.: Dust storms generated by mesoscale cold fronts in the Tarim Basin, Northwest China, Geophys. Res., Lett., 32, L06807, https://doi.org/10.1029/2004GL021776, 2005.

Aoki, T., Motoyoshi, H., Kodama, Y., Yasunari, T. J., Sugiura, K., and Kobayashi, H.: Atmospheric aerosol deposition on snow surfaces and its effect on albedo, SOLA, 2, 13-16, https://doi.org/10.2151/sola.2006-004, 2006.

Arimoto, R., Zhang, X. Y., Huebert, B .J., Kang, C. H., Savoie, D. L., Prospero, J. M., Sage, S. K., Schloesslin, C. A., Khaing, H. M., and Oh, S. N.: Chemical composition of atmospheric aerosols from Zhenbeitai, China, and Gosan, South Korea, during ACE-Asia, J. Geophys. Res., 109, D19S04, https://doi.org/10.1029/2003JD004323, 2004.

Arimoto, R., Kim, Y. J., Kim, Y. P., Quinn, P. K., Bates, T. S., Anderson, T. L., Gong, S., Uno, I., Chin, M., Huebert, B. J., Clarke, A. D., Shinozuka, Y., Weber, R. J., Anderson, J. R., Guazzotti, S. A., Sullivan, R. C., Sodeman, D. A., Prather, K. A., and Sokolik, I. N.: Characterization of Asian dust during ACE-Asia, Global Planet. Change, 52, 23-56, https://doi.org/10.1016/j.gloplacha.2006.02.013, 2006.

Arya, S. P.: Air Pollution Meteorology and Dispersion, 310 pp., Oxford University Press, New York, 1999.

Bergin, M. H., Cass, G. R., Xu, J., Fang, C., Zeng, L. M., Yu, T., Salmon, L. G., Kiang, C. S., Tang, X. Y., Zhang, Y. H., and Chameides, W. L.: Aerosol radiative, physical, and chemical properties in Beijing during June 1999, J. Geophys. Res., 106, 17969-17980, https://doi.org/10.1029/2001JD900073, 2001.

Bi, J., Huang, J., Fu, Q., Wang, X., Shi, J., Zhang, W., Huang, Z., and Zhang B.: Toward characterization of the aerosol optical properties over Loess Plateau of Northwestern China, J. Quant. Spectrosc. Ra., 112, 346-360, https://doi.org/10.1016/j.jqsrt.2010.09.006, 2011.

Bi, J., Huang, J., Fu, Q., Ge, J., Shi, J., Zhou, T., and Zhang, W.: Field measurement of clear-sky solar irradiance in Badain Jaran Desert of Northwestern China, J. Quant. Spectroc. Ra., 122, 194207, https://doi.org/10.1016/j.jqsrt.2012.07.025, 2013.

Bi, J., Shi, J., Xie, Y., Liu, Y., Takamura, T., and Khatri, P.: Dust aerosol characteristics and shortwave radiative impact at a Gobi 
Desert of Northwest China during the spring of 2012, J. Meteor. Soc. Jpn, Ser. II, 92A, 33-56, https://doi.org/10.2151/jmsj.2014A03, 2014.

Bi, J., Huang, J., Holben, B., and Zhang, G.: Comparison of key absorption and optical properties between pure and transported anthropogenic dust over East and Central Asia, Atmos. Chem. Phys., 16, 15501-15516, https://doi.org/10.5194/acp-16-155012016, 2016.

Campbell, J. R., Hlavka, D. L., Welton, E. J., Flynn, C. J., Turner, D. D., Spinhirne, J. D., Scott, V. S., and Hwang, I. H.: Full-Time, eye-safe cloud and aerosol lidar observation at Atmospheric Radiation Measurement program sites: Instruments and data processing, J. Atmos. Ocean. Technol., 19, 431-442, https://doi.org/10.1175/15200426(2002)019<0431:FTESCA>2.0.CO;2, 2002.

Cao, J. J., Lee, S. C., Zhang, X. Y., Chow, J. C., An, Z. S., Ho, K. F., Watson, J. G., Fung, K., Wang, Y. Q., and Shen, Z. X.: Characterization of airborne carbonate over a site on Asian dust source regions during 2002 spring and its climatic and environmental significance, J. Geophys. Res., 110, D03203, https://doi.org/10.1029/2004JD005244, 2005.

Che, H., Zhang, X. Y., Chen, H. B., Damiri, B., Goloub, P., Li, Z., Zhang, X., Wei, Y., Zhou, H., Dong, F., Li, D., and Zhou, T.: Instrument calibration and aerosol optical depth validation of the China Aerosol Remote Sensing Network, J. Geophys. Res., 114, D03206, https://doi.org/10.1029/2008JD011030, 2009.

Che, H., Zhang, X.-Y., Xia, X., Goloub, P., Holben, B., Zhao, H., Wang, Y., Zhang, X.-C., Wang, H., Blarel, L., Damiri, B., Zhang, R., Deng, X., Ma, Y., Wang, T., Geng, F., Qi, B., Zhu, J., Yu, J., Chen, Q., and Shi, G.: Ground-based aerosol climatology of China: aerosol optical depths from the China Aerosol Remote Sensing Network (CARSNET) 2002-2013, Atmos. Chem. Phys., 15, 7619-7652, https://doi.org/10.5194/acp15-7619-2015, 2015.

Cheng, T., Lu, D., Wang, G., and Xu, Y.: Chemical characteristics of Asian dust aerosol from Hunshan Dake Sandland in Northern China, Atmos. Environ., 39, 2903-2911, https://doi.org/10.1016/j.atmosenv.2004.12.045, 2005.

Covert, D. S., Charlson, R. J., and Ahlquist, N. C.: A study of the relationship of chemical composition and humidity to light scattering by aerosols, J. Appl. Meteo., 11, 968-976, 1972.

Creamean, J. M., Suski, K. J., Rosenfeld, D., Cazorla, A., DeMott, P. J., Sullivan, R. C., White, A. B., Ralph, F. M., Minnis, P., Comstock, J. M., Tomlinson, J. M., and Prather, K. A.: Dust and biological aerosols from the Sahara and Asia influence precipitation in the western U.S., Science, 339, 1572-1578, https://doi.org/10.1126/science.1227279, 2013.

Delene, D. and Ogren, J. A.: Variability of aerosol optical properties at four North American surface monitoring sites, J. Atmos. Sci., 59, 1135-1150, https://doi.org/10.1175/15200469(2002)059<1135:VOAOPA>2.0.CO;2, 2002.

Dubovik, O., Holben, B. N., Eck, T. F., Smirnov, A., Kaufman, Y. J., King, M. D., Tanré, D., and Slutsker, I.: Variability of absorption and optical properties of key aerosol types observed in worldwide locations, J. Atmos. Sci., 59, 590-608, 2002.

Eck, T. F., Holben, B. N., Dubovik, O., Smirnov, A., Goloub, P., Chen, H. B., Chatenet, B., Gomes, L., Zhang, X.-Y, Tsay, S.C., Ji, Q., Giles, D., and Slutsker, I.: Columnar aerosol optical properties at AERONET sites in central eastern Asia and aerosol transport to the tropical mid-Pacific, J. Geophys. Res., 110, D06202, https://doi.org/10.1029/2004JD005274, 2005.

Ge, J., Su, J., Ackerman, T. P., Fu, Q., Huang, J., and Shi, J.: Dust aerosol optical properties retrieval and radiative forcing over northwest China during the 2008 ChinaU.S. joint field experiment, J. Geophys. Res., 115, D00K12, https://doi.org/10.1029/2009JD013263, 2010.

Ge, J. M., Liu, H., Huang, J., and Fu, Q.: Taklimakan Desert nocturnal low-level jet: climatology and dust activity, Atmos. Chem. Phys., 16, 7773-7783, https://doi.org/10.5194/acp-167773-2016, 2016.

Ginoux, P., Prospero, J. M., Gill, T. E., Hsu, N. C., and Zhao, M.: Global-scale attribution of anthropogenic and natural sources and their emission rates based on MODIS Deep Blue aerosol products, Rev. Geophys., 50, RG3005, https://doi.org/10.1029/2012RG000388, 2012.

Guan, X., Huang, J., Zhang, Y., Xie, Y., and Liu, J.: The relationship between anthropogenic dust and population over global semi-arid regions, Atmos. Chem. Phys., 16, 5159-5169, https://doi.org/10.5194/acp-16-5159-2016, 2016.

Hansen, J., Sato, M., and Ruedy, R.: Radiative forcing and climate response, J. Geophys. Res., 102, 6831-6864, 1997.

Holben, B. N., Eck, T. F., Slutsker, I., Tanre, D., Buis, J. P., Setzer, A., Vermote, E., Reagan, J. A., Kaufman, Y. J., Nakajima, T., Lavenu, F., Jankowiak, F., and Smirnov, A.: AERONET - A federated instrument network and data archive for aerosol characterization, Remote Sens. Environ., 66, 1-16, 1998.

Huang, J., Minnis, P., Lin, B., Yi, Y., Khaiyer, M. M., Arduini, R. F., Fan, A., and Mace, G. G.: Advanced retrievals of multilayered cloud properties using multispectral measurements, J. Geophys. Res., 110, D15S18, https://doi.org/10.1029/2004JD005101, 2005.

Huang, J., Lin, B., Minnis, P., Wang, T., Wang, X., Hu, Y., Yi, Y., and Ayers, J. K.: Satellite-based assessment of possible dust aerosols semi-direct effect on cloud water path over East Asia, Geophys. Res. Lett., 33, L19802, https://doi.org/10.1029/2006GL026561, 2006.

Huang, J., Minnis, P., Chen, B., Huang, Z., Liu, Z., Zhang, Q., Yi, Y., and Ayers, J. K.: Long-range transport and vertical structure of Asian dust from CALIPSO and surface measurements during PACDEX, J. Geophys. Res., 113, D23212, https://doi.org/10.1029/2008JD010620, 2008a.

Huang, J., Zhang, W., Zuo, J., Bi, J., Shi, J., Wang, X., Chang, Z., Huang, Z., Yang, S., Zhang, B., Wang, G., Feng, G., Yuan, J., Zhang, L., Zuo, H., Wang, S., Fu, C., and Chou, J.: An overview of the semi-arid climate and environment research observatory over the Loess Plateau, Adv. Atmos. Sci., 25, 906-921, https://doi.org/10.1007/s00376-008-0906-7, 2008b.

Huang, J., Fu, Q., Su, J., Tang, Q., Minnis, P., Hu, Y., Yi, Y., and Zhao, Q.: Taklimakan dust aerosol radiative heating derived from CALIPSO observations using the Fu-Liou radiation model with CERES constraints, Atmos. Chem. Phys., 9, 4011-4021, https://doi.org/10.5194/acp-9-4011-2009, 2009.

Huang, J., Minnis, P., Yan, H., Yi, Y., Chen, B., Zhang, L., and Ayers, J. K.: Dust aerosol effect on semi-arid climate over Northwest China detected from A-Train satellite measurements, Atmos. Chem. Phys., 10, 6863-6872, https://doi.org/10.5194/acp10-6863-2010, 2010. 
Huang, J., Fu, Q., Zhang, W., Wang, X., Zhang, R., Ye, H., and Warren, S. G.: Dust and black carbon in seasonal snow across northern China, Bull. Amer. Meteor. Soc., 92, 175-181, https://doi.org/10.1175/2010BAMS3064.1, 2011.

Huang, J., Wang, T., Wang, W., Li, Z., and Yan, H.: Climate effects of dust aerosols over East Asian arid and semiarid regions, J. Geophys. Res., 119, 11398-11416, https://doi.org/10.1002/2014JD021796, 2014.

Huang, J., Yu, H., Guan, X., Wang, G., and Guo, R.: Accelerated dryland expansion under climate change, Nature Clim. Change, 6, 166-171, https://doi.org/10.1038/nclimate2837, 2016.

Huang, J. P., Liu, J. J., Chen, B., and Nasiri, S. L.: Detection of anthropogenic dust using CALIPSO lidar measurements, Atmos. Chem. Phys., 15, 11653-11665, https://doi.org/10.5194/acp-1511653-2015, 2015.

Huang, K., Zhuang, G., Li, J., Wang, Q., Sun, Y., Lin, Y., and Fu, J. S.: Mixing of Asian dust with pollution aerosol and the transformation of aerosol components during the dust storm over China in spring 2007, J. Geophys. Res., 115, D00K13, https://doi.org/10.1029/2009JD013145, 2010.

Huang, Z., Huang, J., Bi, J., Wang, G., Wang, W., Fu, Q., Li, Z., Tsay, S.-C., and Shi, J.: Dust aerosol vertical structure measurements using three MPL lidars during 2008 China-U.S. joint dust field experiment, J. Geophys. Res., 115, D00K15, https://doi.org/10.1029/2009JD013273, 2010.

Huebert, B. J., Bates, T., Russell, P. B., Shi, G., Kim, Y. J., Kawamura, K., Carmichael, G., and Nakajima, T.: An overview of ACE-Asia: Strategies for quantifying the relationships between Asian aerosols and their climatic impacts, J. Geophys. Res., 108, 8633, https://doi.org/10.1029/2003JD003550, 2003.

Intergovernmental Panel on Climate Change (IPCC): Climate Change 2013: The Physical Science Basis, Contribution of Working Group I to the Fifth Assessment Report of the Intergovernmental Panel on Climate Change, edited by: Stocker, T. F., Qin, D., Plattner, G.-K., Tignor, M., Allen, S. K., Boschung, J., Nauels, A., Xia, Y., Bex, V., and Midgley, P. M.: Cambridge University Press, Cambridge, United Kingdom and New York, NY, USA, 1535 pp., 2013.

Jickells, T., An, Z., Andersen, K., Baker, A., Bergametti, G., Brooks, N., Cao, J., Boyd, P., Duce, R., Hunter, K., Kawahata, H., Kubilay, N., laRoche, J., Liss, P., Mahowald, N., Prospero, J., Ridgwell, A., Tegen, I., and Torres, R.: Global iron connections between desert dust, ocean biogeochemistry, and climate, Science, 308, 67-71, https://doi.org/10.1126/science.1105959, 2005.

Kai, K., Nagata, Y., Tsunematsu, N., Matsumura, T., Kim, H.-S., Matsumoto, T., Hu, S., Zhou, H., Abo, M., and Nagai, T.: The structure of the dust layer over the Taklimakan Desert during the dust storm in April 2002 as observed using a depolarization lidar, J. Meteor. Soc. Jpn, 86, 1-16, https://doi.org/10.2151/jmsj.86.1, 2008.

Khatri, P. and Takamura, T.: An algorithm to screen cloud-affected data for sky radiometer data analysis, J. Meteor. Soc. Jpn, 87, 189-204, https://doi.org/10.2151/jmsj.87.189, 2009.

Kobayashi, A., Hayashida, S., Okada, K., and Iwasaka, Y.: Measurements of the polarization properties of Kosa (Asian Dust storm) particles by a Laser Radar in spring 1983, J. Meteor. Soc., Jpn., 63, 144-149, 1985.
Lafon, S., Rajot, J.-L., Alfaro, S. C., and Gaudichet, A.: Quantification of iron oxides in desert aerosol, Atmos. Environ., 38, 12111218, 2004.

Lafon, S., Sokolik, I. N., Rajot, J. L., Caquineau, S., and Guadichet, A.: Characterization of iron oxides in mineral dust aerosols: Implications for light absorption, J. Geophys. Res., 111, D21207, https://doi.org/10.1029/2005JD007016, 2006.

Li, C., Marufu, L. T., Dickerson, R. R., Li, Z., Wen, T., Wang, Y., Wang, P., Chen, H., and Stehr, J. W.: In situ measurements of trace gases and aerosol optical properties at a rural site in northern China during East Asian Study of Tropospheric Aerosols: An International Regional Experiment 2005, J. Geophys. Res., 112, D22S04, https://doi.org/10.1029/2006JD007592, 2007.

Li, C., Tsay, S.-C., Fu, J. S., Dickerson, R. R., Ji, Q., Bell, S. W., Gao, Y., Zhang, W., Huang, J., Li, Z., and Chen, H.: Anthropogenic air pollution observed near dust source regions in northwestern China during springtime 2008, J. Geophys. Res., 115, D00K22, https://doi.org/10.1029/2009JD013659, 2010.

Li, W. J. and Shao, L. Y.: Observation of nitrate coatings on atmospheric mineral dust particles, Atmos. Chem. Phys., 9, 18631871, https://doi.org/10.5194/acp-9-1863-2009, 2009.

Li, Z., Li, C., Chen, H., Tsay, S.-C., Holben, B., Huang, J., Li, B., Maring, H., Qian, Y., Shi, G., Xia, X., Yin, Y., Zheng, Y., and Zhuang, G.: East Asian Studies of Tropospheric Aerosols and their Impact on Regional Climate (EAST-AIRC): An overview, J. Geophys. Res., 116, D00K34, https://doi.org/10.1029/2010JD015257, 2011.

Li, Z., Lau, W. K.-M., Ramanathan, V., Wu, G., Ding, Y., Manoj, M. G., Liu, J., Qian, Y., Li, J., Zhou, T., Fan, J., Rosenfeld, D., Ming, Y., Wang, Y., Huang, J., Wang, B., Xu, X., Lee, S.-S., Gribb, M., Zhang, F., Yang, X., Zhao, C., Takemura, T., Wang, K., Xia, X., Yin, Y., Zhang, H., Guo, J., Zhai, P. M., Sugimoto, N., Babu, S. S., and Brasseur, G. P.: Aerosol and monsoon climate interactions over Asia, Rev. Geophys., 54, 866-929, https://doi.org/10.1002/2015RG000500, 2016.

Ma, J., He, J., Qi, S., Zhu, G., Zhao, W., Edmunds, W. M., and Zhao, Y.: Groundwater recharge and evolution in the Dunhuang Basin, northwestern China, Appl. Geochem., 28, 19-31, https://doi.org/10.1016/j.apgeochem.2012.10.007, 2013.

Maher, B. A., Prospero, J. M., Mackie, D., Gaiero, D., Hesse, P. P., and Balkanski, Y.: Global connections between aeolian dust, climate and ocean biogeochemistry at the present day and at the last glacial maximum, Earth-Sci. Rev., 99, 61-97, https://doi.org/10.1016/j.earscirev.2009.12.001, 2010.

Mikami, M., Shi, G. Y., Uno, I., Yabuki, S., Iwasaka, Y., Yasui, M., Aoki, T., Tanaka, T. Y., Kurosaki, Y., Masuda, K., Uchiyama, A., Matsuki, A., Sakai, T., Takemi, T., Nakawo, M., Seino, N., Ishizuka, M., Satake, S., Fujita, K., Hara, Y., Kai, K., Kanayama, S., Hayashi, M., Du, M., Kanai, Y., Yamada, Y., Zhang, X. Y., Shen, Z., Zhou, H., Abe, Q., Nagai, T., Tsutsumi, Y. , Chiba, M., and Suzuki, J.: Aeolian dust experiment on climate impact: An overview of JapanChina joint project ADEC, Global Planet. Change, 52, 142-172, https://doi.org/10.1016/j.gloplacha.2006.03.001, 2006.

Murayama, T., Okamoto, H., Kaneyasu, N., Kamataki, H., and Miura, K.: Application of lidar depolarization measurement in the atmospheric boundary layer: Effects of dust and sea-salt particles, J. Geophys. Res., 104, 31781-31792, 1999. 
Nakajima, T., Tonna, G., Rao, R., Boi, P., Kaufman, Y., and Holben, B.: Use of sky brightness measurements from ground for remote sensing of particulate polydispersions, Appl. Opt., 35, 2672-2686, https://doi.org/10.1364/AO.35.002672, 1996.

Nakajima, T., Sekiguchi, M., Takemura, T., Uno, I., Higurashi, A., Kim, D., Sohn, B. J., Oh, S.-N., Nakajima, T. Y., Ohta, S., Okada, I., Takamura, T, and Kawamoto, K.: Significance of direct and indirect radiative forcings of aerosols in the East China Sea region, J. Geophys. Res., 108, 8658, https://doi.org/10.1029/2002JD003261, 2003.

Nie, W., Ding, A., Wang, T., Kerminen, V.-M., George, C., Xue, L., Wang, W., Zhang, Q., Petäjä, T., Qi, X., Gao, X., Wang, X., Yang, X., Fu, C., and Kulmala, M.: Polluted dust promotes new particle formation and growth, Sci. Rep., 4, 6634, https://doi.org/10.1038/srep06634, 2014.

Petzold, A., Kramer, H., and Schönlinner, M.: Continuous measurement of atmospheric black carbon using a multi-angle absorption photometer, Environ. Sci. Poll. Res., 4, 78-82, 2002.

Petzold, A., Schloesser, H., Sheridan, P. J., Arnott, W. P., Ogren, J. A., and Virkkula A.: Evaluation of multiangle absorption photometry for measuring aerosol light absorption, Aerosol Sci. Tech., 39, 40-51, https://doi.org/10.1080/027868290901945, 2005.

Qian, Y., Yasunnari, T. J., Doherty, S. J., Flanner, M. G., Lau, W. K.-M., Ming, J., Wang, H., Wang, M., Warren, S. G., and Zhang, R.: Light-absorbing particles in snow and ice: Measurement and modeling of climatic and hydrological impact, Adv. Atmos. Sci., 32, 64-91, https://doi.org/10.1007/s00376-014-0010-0, 2014.

Ramanathan, V., Crutzen, P. J., Kiehl, J. T., and Rosenfeld, D.: Aerosols, climate, and the hydrological cycle, Science, 294, 2119-2124, https://doi.org/10.1126/science.1064034, 2001.

Rienecker, M. M., Suarez, M. J., Gelaro, R., Todling, R., Bacmeister, J., Liu, E., Bosilovich, M. G., Schubert, S. D., Takacs, L., Kim, G.-K., Bloom, S., Chen, J., Collins, D., Conaty, A., Silva, A. da, Gu, W., Joiner, J., Koster, R. D., Lucchesi, R., Molod, A., Owens, T., Pawson, S., Pegion, P., Redder, C. R., Reichle, R., Robertson, F. R., Ruddick, A. G., Sienkiewicz, M., and Woollen, J.: MERRA: NASA's Modern-Era Retrospective Analysis for Research and Applications, J. Climate, 24, 3624-3648, https://doi.org/10.1175/JCLI-D-11-00015.1, 2011.

Rosenfeld, D., Rudich, Y., and Lahav, R.: Desert dust suppressing precipitation: A possible desertification feedback loop, Proc. Natl. Acad. Sci. U.S.A., 98, 5975-5980, 2001.

Shao, Y., Wyrwoll, K.-H., Chappel, A., Huang, J., Lin, Z., McTainsh, G., Mikami, M., Tanaka, T., Wang, X., and Yoon, S.: Dust cycle: An emerging core theme in Earth system science, Aeolian Res., 2, 181-204, 2011.

Shimizu, A., Sugimoto, N., Matsui, I., Arao, K., Uno, I., Murayama, T., Kagawa, N., Aoki, K., Uchiyama, A., and Yamazaki, A.: Continuous observations of Asian dust and other aerosol by polarization lidars in China and Japan during ACE-Asia, J. Geophys. Res., 109, D19S17, https://doi.org/10.1029/2002JD003253, 2004.

Sokolik, I. N. and Toon, O. B.: Incorporation of mineralogical composition into models of the radiative properties of mineral aerosol from UV to IR wavelengths, J. Geophys. Res., 104, 9423-9444, 1999.

Sun, J., Zhang, M., and Liu, T.: Spatial and temporal characteristics of dust storms in China and its surrounding regions, 1960-1990:
Relations to source area and climate, J. Geophys. Res., 106, 10325-10333, https://doi.org/10.1029/2000JD900665, 2001.

Takamura, T., Nakajima, T., and SKYNET community group: Overview of SKYNET and its Activities, Opt. Puray Apl., 37, 3303-3308, 2004.

Tegen, I. and Fung, I.: Contribution to the atmospheric mineral aerosol load from land surface modification, J. Geophys. Res. 100, 18707-18726, https://doi.org/10.1029/95JD02051, 1995.

Torres, O., Tanskanen, A., Veihelmann, B., Ahn, C., Braak, R., Bhartia, P. K., Veefkind, P., and Levelt, P.: Aerosols and surface UV products from Ozone Monitoring Instrument observations: An overview, J. Geophys. Res., 112, D24S47, https://doi.org/10.1029/2007JD008809, 2007.

Uchiyama, A., Yamazaki, A., Togawa, H., Asano, J., and Shi, G.-Y.: Single scattering albedo of Aeolian dust as inferred from skyradiometer and in situ ground-based measurement, SOLA, 1, 209-212, https://doi.org/10.2151/sola.2005-054, 2005.

Uno, I., Eguchi, K., Yumimoto, K., Takemura, T., Shimizu, A., Uematsu, M., Liu, Z., Wang, Z., Hara, Y., and Sugimoto, N.: Asian dust transported one full circuit around the globe, Nature Geosci., 2, 557-560, https://doi.org/10.1038/NGEO583, 2009.

Uno, I., Eguchi, K., Yumimoto, K., Liu, Z., Hara, Y., Sugimoto, N., Shimizu, A., and Takemura, T.: Large Asian dust layers continuously reached North America in April 2010, Atmos. Chem. Phys., 11, 7333-7341, https://doi.org/10.5194/acp-117333-2011, 2011.

Wang, G., Huang, J., Guo, W., Zuo, J., Wang, J., Bi, J., Huang, Z., and Shi, J.: Observation analysis of land-atmosphere interactions over the Loess Plateau of northwest China, J. Geophys. Res., 115, D00K17, https://doi.org/10.1029/2009JD013372, 2010.

Wang, K. and Dickinson, R. E.: Global atmospheric downward longwave radiation at the surface from ground-based observations, satellite retrievals, and reanalyses, Rev. Geophys., 51, 150 185, https://doi.org/10.1002/rog.20009, 2013.

Wang, W., Huang, J., Minnis, P., Hu, Y., Li, J., Huang, Z., Ayers, J. K., and Wang, T.: Dusty cloud properties and radiative forcing over dust source and downwind regions derived from A-Train data during the Pacific Dust Experiment, J. Geophys. Res., 115, D00H35, https://doi.org/10.1029/2010JD014109, 2010.

Wang, X., Huang, J., Ji, M., and Higuchi, K.: Variability of East Asia dust events and their long-term trend, Atmos. Environ., 42, 3156-3165, https://doi.org/10.1016/j.atmosenv.2007.07.046, 2008.

Wang, X., Doherty, S. J., and Huang, J.: Black carbon and other light-absorbing impurities in snow across Northern China, J. Geophys. Res., 118, 1471-1492, https://doi.org/10.1029/2012JD018291, 2013.

Wang, X., Pu, W., Shi, J., Bi, J., Zhou, T., Zhang, X., and Ren, Y.: A comparison of the physical and optical properties of anthropogenic air pollutants and mineral dust over Northwest China, J. Meteorol. Res., 29, 180-200, https://doi.org/10.1007/s13351015-4092-0, 2015.

Welton, E. J., Voss, K. J., Gordon, H. R., Maring, H., Smirnov, A., Holben, B., Schmid, B., Livingston, J. M., Russell, P. B., Durkee, P. A., Formenti, P., and Andreae, M. O.: Groundbased lidar measurements of aerosols during ACE-2: Instrument description, results, and comparisons with other groundbased and airborne measurements, Tellus B, 52, 636-651, https://doi.org/10.1034/j.1600-0889.2000.00025.x, 2000. 
Wu, G. X., Li, Z. Q., Fu, C. B., Zhang, X. Y., Zhang, R. Y., Zhang, R. H., Zhou, T. J., Li, J. P., Li, J. D., Zhou, D. G., Wu, L., Zhou, L. T., He, B., and Huang, R. H.: Advances in studying interactions between aerosols and monsoon in China, Sci. China Earth Sci., 59, 1-16, https://doi.org/10.1007/s11430-015-5198-z, 2016.

Xia, X., Zong, X., Cong, Z., Chen, H., Kang, S., and Wang, P.: Baseline continental aerosol over the central Tibetan plateau and a case study of aerosol transport from South Asia, Atmos. Environ., 45, 7370-7378, https://doi.org/10.1016/j.atmosenv.2011.07.067, 2011.

Xu, J., Bergin, M. H., Yu, X., Liu, G., Zhao, J., Marrico, C. M., and Baumann, K.: Measurement of aerosol chemical, physical, and radiative properties in the Yangtze delta region of China, Atmos. Environ., 36, 161-173, https://doi.org/10.1016/S13522310(01)00455-1, 2002.

Xu, J., Bergin, M. H., Greenwald, R., Schauer, J. J., Shafer, M. M., Jaffrezo, J. L., and Aymoz, G.: Aerosol chemical, physical, and radiative characteristics near a desert source region of northwest China during ACE-Asia, J. Geophys. Res., 109, D19S03, https://doi.org/10.1029/2003JD004239, 2004.
Yan, H.: Aerosol scattering properties in northern China, Atmos. Environ., 41, 6916-6922, https://doi.org/10.1016/j.atmosenv.2007.04.052, 2007.

Yan, P., Tang, J., Huang, J., Mao, J. T., Zhou, X. J., Liu, Q., Wang, Z. F., and Zhou, H. G.: The measurement of aerosol optical properties at a rural site in Northern China, Atmos. Chem. Phys., 8, 2229-2242, https://doi.org/10.5194/acp-8-2229-2008, 2008.

Yin, Y. and Chen, L.: The effects of heating by transported dust layers on cloud and precipitation: a numerical study, Atmos. Chem. Phys., 7, 3497-3505, https://doi.org/10.5194/acp-7-3497-2007, 2007.

Zhang, X., Arimoto, R., and An, Z.: Dust emission from Chinese desert sources linked to variations in atmospheric circulation, J. Geophys. Res., 102, 28041-28047, https://doi.org/10.1029/97JD02300, 1997.

Zhao, T. L., Gong, S. L., Zhang, X. Y., Blanchet, J.-P., McKendry, I. G., and Zhou, Z. J.: A simulated climatology of Asian Dust aerosol and its Trans-Pacific transport. Part I: Mean climate and validation, J. Climate, 19, 88-103, https://doi.org/10.1175/JCLI3605.1, 2006. 